\title{
Propagation of biases in humidity in the estimation of global irrigation water
}

\author{
Y. Masaki, N. Hanasaki, K. Takahashi, and Y. Hijioka \\ National Institute for Environmental Studies, 16-2 Onogawa, Tsukuba, Ibaraki, 305-8506, Japan \\ Correspondence to: Y. Masaki (masaki.yoshimitsu@nies.go.jp) \\ Received: 25 December 2014 - Published in Earth Syst. Dynam. Discuss.: 26 January 2015 \\ Revised: 4 June 2015 - Accepted: 5 June 2015 - Published: 20 July 2015
}

\begin{abstract}
Future projections on irrigation water under a changing climate are highly dependent on meteorological data derived from general circulation models (GCMs). Since climate projections include biases, bias correction is widely used to adjust meteorological elements, such as the atmospheric temperature and precipitation, but less attention has been paid to biases in humidity. Hence, in many cases, uncorrected humidity data have been directly used to analyze the impact of future climate change. In this study, we examined how the biases remaining in the humidity data of five GCMs propagate into the estimation of irrigation water demand and consumption from rivers using the global hydrological model (GHM) H08. First, to determine the effects of humidity bias across GCMs, we ran H08 with GCM-based meteorological forcing data sets distributed by the Inter-Sectoral Impact Model Intercomparison Project (ISI-MIP). A state-of-the-art bias correction method was applied to the data sets without correcting biases in humidity. Differences in the monthly relative humidity amounted to 11.7 to $20.4 \% \mathrm{RH}$ (percentage relative humidity) across the GCMs and propagated into differences in the estimated irrigation water demand, resulting in a range between 1152.6 and $1435.5 \mathrm{~km}^{3} \mathrm{yr}^{-1}$ for 1971-2000. Differences in humidity also propagated into future projections. Second, sensitivity analysis with hypothetical humidity biases of $\pm 5 \% \mathrm{RH}$ added homogeneously worldwide revealed the large negative sensitivity of irrigation water abstraction in India and East China, which are heavily irrigated. Third, we performed another set of simulations with bias-corrected humidity data to examine whether bias correction of the humidity can reduce uncertainties in irrigation water across the GCMs. The results showed that bias correction, even with a primitive methodology that only adjusts the monthly climatological relative humidity, helped reduce uncertainties across the GCMs: by using bias-corrected humidity data, the uncertainty ranges of irrigation water demand across the five GCMs were successfully reduced from 282.9 to $167.0 \mathrm{~km}^{3} \mathrm{yr}^{-1}$ for the present period, and from 381.1 to $214.8 \mathrm{~km}^{3} \mathrm{yr}^{-1}$ for the future period (RCP8.5, 2070-2099). Although different GHMs have different sensitivities to atmospheric humidity because different types of potential evapotranspiration formulae are implemented in them, bias correction of the humidity should be applied to forcing data, particularly for the evaluation of evapotranspiration and irrigation water.
\end{abstract}

\section{Introduction}

Recent ongoing global warming is expected to change current hydroclimatological environments at the global scale. Since fresh water is essential for various industrial and social activities of human beings, its availability plays a crucial role in the sustainable development of society.

Agriculture is one of the human activities that are highly susceptible to hydroclimatological conditions. Irrigated wa- ter is supplied to cropland to compensate for the deficit in the soil water content, which affects crop growth. Since soil water is primarily consumed through evapotranspiration, which is sensitive to meteorological conditions, the amount of required irrigation water varies with the meteorological conditions. According to Vörösmarty et al. (2005) (Tables 7.3 and 7.4), the total amount of global freshwater withdrawal was $3560 \mathrm{~km}^{3} \mathrm{yr}^{-1}$ for $1995-2000,2480 \mathrm{~km}^{3} \mathrm{yr}^{-1}$ (70\% of the total withdrawal) of which was supplied for agricultural 
use, and the consumption through evapotranspiration from irrigated cropland amounted to $1210 \mathrm{~km}^{3} \mathrm{yr}^{-1}$ (34\% of the total human withdrawal and $49 \%$ of the total agricultural withdrawal). In Asia, a larger proportion of abstracted water is consumed through evapotranspiration $(52 \%$ of the total human withdrawal and $59 \%$ of the total agricultural withdrawal) than the global average. Moreover, the volume of irrigation water is expected to increase in the future because of an increase in evapotranspiration from cropland under warmer climates (e.g., Wada et al., 2013) and the expansion of irrigated cropland to meet the increasing demand for food owing to the increase in the world population (e.g., Bruinsma, 2011; Elliott et al., 2014). Precise estimation of the amount of irrigation water abstraction is crucial for the sustainable use of available water in the future.

To quantitatively evaluate future irrigation water, we must substantially rely on hydrological simulation. However, there are fundamental difficulties in the estimation because there are many possible errors and uncertainties in the data sets (meteorological data sets, land use data, etc.), calculation schemes (evapotranspiration, runoff, river flow, etc.) and parameters. Moreover, there are also difficulties in incorporating irrigation schemes that are able to represent realistic irrigation management and performance. In fact, different general circulation models (GCMs) and global hydrological models (GHMs) give different estimates. Wisser et al. (2008) showed that the discrepancies in the estimation stem from both meteorological and irrigated area data. Recently, the Inter-Sectoral Impact Model Intercomparison Project (ISIMIP) set the estimation of uncertainties in both GCMs and GHMs through intermodel comparison as one of its goals (Warszawski et al., 2014).

GCM biases are one of the substantial sources of uncertainty in future climate projections. For over a decade, we have made considerable effort to remove GCM biases from the temperature and precipitation data because these meteorological elements are crucial for analyzing the impact of climate change. However, hydrological simulations require other meteorological elements in addition to these elements. Solving water and heat budgets at the ground surface basically requires seven meteorological elements (atmospheric temperature, precipitation, short- and longwave downward radiation, wind velocity, pressure and humidity). Less attention has been paid to GCM biases of meteorological elements other than temperature and precipitation. Haddeland et al. (2012) intensively examined the compound effects of the bias correction of radiation, wind and humidity, and showed that bias correction has an impact on absolute values of evapotranspiration but less impact on relative changes. Moreover, global humidity observation data sets contain uncertainties originating from the accuracy of measurements, grid sampling (Willett et al., 2013) and the spatial variability within land cells. Knowing the sensitivity of irrigation water to humidity conditions at different locations would help clarify the
Table 1. Bias-corrected meteorological data used in this study. The data sets were distributed by the ISI-MIP, after bias correction by the method proposed by Hempel et al. (2013).

\begin{tabular}{ll}
\hline Element & Bias correction \\
\hline Average temperature & additive \\
Total precipitation & multiplicative \\
Snowfall & multiplicative \\
Shortwave radiation & multiplicative \\
Longwave radiation & multiplicative \\
Near-surface wind speed & multiplicative \\
Surface pressure & multiplicative \\
\hline Relative humidity & uncorrected \\
\hline
\end{tabular}

maximum expected uncertainty ranges in the estimation of irrigation water and their geographical susceptibility.

In the framework of the recent research project on climate change impact assessment, the ISI-MIP has provided GCMgenerated meteorological data sets that were adjusted by a sophisticated bias correction method developed by Hempel et al. (2013). Although most of the meteorological elements used in GHMs have been corrected by this method, the relative humidity remains uncorrected. It is important to quantitatively evaluate the size of the humidity biases existing in the original GCM data and the extent to which they affect the estimation of irrigation water. In this study, we examine possible uncertainty sources in estimating irrigation water consumption via evapotranspiration by focusing on the propagation of uncertainties in humidity data. We also examine whether uncertainties in irrigation water consumption across GCMs can be reduced if bias correction is applied to the humidity.

The data and analysis methods are described in Sect. 2 and the results and discussion are given in Sects. 3 and 4, respectively.

\section{Data and methods}

\subsection{Bias-corrected meteorological data}

We used bias-corrected meteorological data sets distributed by the ISI-MIP for driving GHM H08 (details of the model are given in Sect. 2.2). Five GCMs based on the Coupled Model Intercomparison Project Phase 5 (CMIP5) were used: GFDL-ESM2M (NOAA Geophysical Fluid Dynamics Laboratory), HadGEM2-ES (Met Office Hadley Centre with contribution by Instituto Nacional de Pesquisas Espaciais), IPSL-CM5A-LR (Institut Pierre-Simon Laplace), MIROC-ESM-CHEM (Japan Agency for Marine-Earth Science and Technology, Atmosphere and Ocean Research Institute (University of Tokyo) and National Institute for Environmental Studies) and NorESM1-M (Norwegian Climate Centre). Hereafter, we abbreviate these GCMs to GFDL, 
HadGEM, IPSL, MIROC and NorESM, respectively. Bias correction was applied to the meteorological elements listed in Table 1 using the method of Hempel et al. (2013) with observation-based WATCH meteorological data sets (Weedon et al., 2011) for 1960-1999. The bias in relative humidity in the GCMs has remained uncorrected because of difficulties in preserving physical consistency between humidityrelated variables (relative/specific humidity, vapor pressure), the atmospheric temperature and the pressure after bias correction (ISI-MIP, 2012). The geographical resolution of all meteorological data was commonly adjusted to $0.5^{\circ} \times 0.5^{\circ}$. Future projections were made under four representative concentration pathways (RCPs 2.6, 4.5, 6.0 and 8.5) (Moss et al., 2010; van Vuuren et al., 2011).

\subsection{Hydrological model}

The hydrological model used in this study was $\mathrm{H} 08$ (Hanasaki et al., 2008a, b). The model solves both the water and energy balances at a time step of 1 day with global coverage at a resolution of $0.5^{\circ} \times 0.5^{\circ}$. The model consists of six submodels (land surface hydrology, river routing, crop growth, water abstraction, reservoir operation and environmental flow requirement), but only the first four submodels were employed in this study. The land surface hydrology submodel solves the water and energy balances. The submodel solves the water balance using simple and basic physical hydrological processes that are suitable for global-scale simulation. A $1 \mathrm{~m}$ leaky bucket is assumed in the model: the soil moisture in each land cell is expressed as water stored in this bucket, and the water slowly drains from the bucket to express the subsurface runoff. The crop growth submodel is a process-based model that is used to estimate the cropgrowing season globally. The water abstraction submodel estimates the human impacts of irrigational, municipal and industrial water abstraction from rivers for consumptive use. The consumptive use of irrigation water was estimated from the deficit in the soil water content compared with a target level in irrigated cropland during the growing season. Details are described in the second half of this section. The water is abstracted from rivers as the first choice if the riverine water is available; the rest of the required water is limitlessly supplied from non-renewable and non-local blue water resources (e.g., groundwater or long-distance transported water; see Rost et al., 2008; Hanasaki et al., 2010). Values for the consumptive use of municipal and industrial water were taken from country-based AQUASTAT data (FAO, 2015). Municipal and industrial water consumption at each land cell were weighted by the population using the Gridded Population of the World, version 3 (GPWv3) (CIESIN and CIAT, 2005). Socioeconomic conditions (e.g., the population and irrigated area) were fixed at those in the year 2000. To stabilize the initial conditions, the hydrological model was spun up using data from 1950 to 1959.
We assumed that irrigation water is supplied to irrigated cropland under the condition that crops are not affected by water stress. The soil water content was maintained at $75 \%$ of the field capacity for all crops except rice $(100 \%)$ during the growing season and for 30 days before the planting date. If there is a deficit relative to this threshold, soil water content was assumed to be supplied by irrigation. The soil water of cropland is consumed through evapotranspiration and lost through runoff. The former was calculated from both the meteorological conditions and the soil water content (see Sect. 2.3), whereas the latter was assumed to vary with the soil water content. The spatial distribution of the irrigated area was fixed at that for the year 2000 based on the data of Siebert et al. (2005) throughout the analysis period. We separately calculated the results for three different water management schemes corresponding to three types of agricultural land use: double-cropping irrigated cropland (we refer to this water management scheme as Mosaic 1 hereafter), single-cropping irrigated cropland (Mosaic 2) and rain-fed cropland (Mosaic 3). Their geographical distributions are shown in Fig. 1. Information on double and single croppings was taken from the cropping intensity reported by Döll and Siebert (2002). We aggregated the three types of water management into a land cell (Mosaic 0) in consideration of their areal fractions in each land cell. We considered the 19 crops (18 crops plus "others") used in Table 7 in Leff et al. (2004) but with an updated geographical distribution for the year 2000 (Monfreda et al., 2008). The crop parameters used to calculate their growth were based on the SWIM code (Krysanova et al., 2000).

In this study, we evaluated two quantities regarding the irrigation water (hereafter, the water volume is reported on a consumption basis): irrigation water demand (IWD) and irrigation water consumption from rivers (IWCR). The IWD gives the cumulative amount of water to be supplied over cropland to compensate for the deficit relative to a threshold soil water content. The soil water is primarily supplied by precipitation under natural conditions and consumed via evapotranspiration, drained by runoff and so forth. Since we assumed that the soil water should be kept at a certain level by irrigation (described in Sect. 2.3 in detail), IWD gives the additional amount of water required to prevent crops from suffering water stress under given meteorological conditions. In other words, the IWD gives the maximum water consumption while maintaining the current agricultural maneuver (geographical distribution of irrigated cropland, cultivars, water management in irrigated cropland, etc.) under idealized conditions without fear of water shortage.

The IWCR gives the irrigation water consumption that can be supplied from rivers and is defined as a proportion of the IWD. In practice, irrigation water is abstracted from various resources (e.g., rivers, local reservoirs, groundwater). Among them, rivers are the largest water resource and their flow is vulnerable to future climate change. Thus, it is important to examine the proportion of IWD that can be supplied 


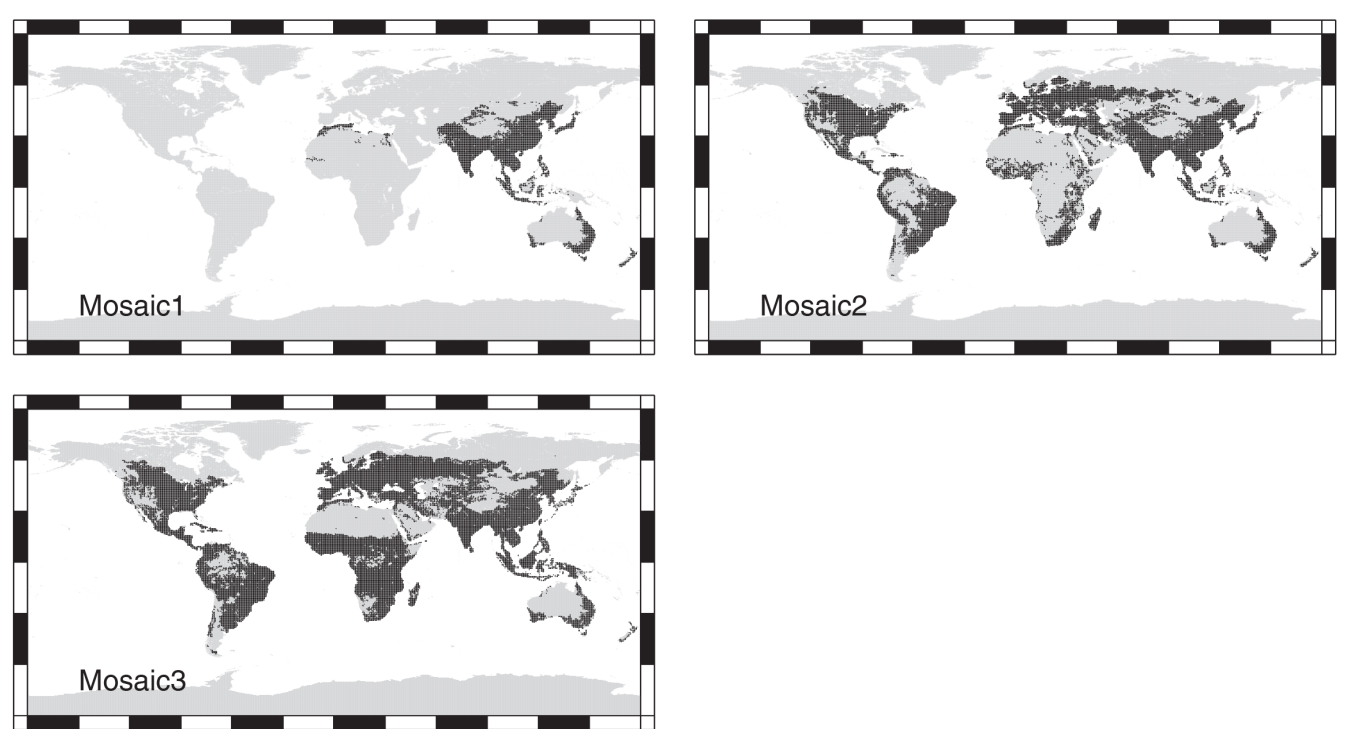

Figure 1. Geographical distribution of irrigated croplands - (a) double cropping each year (Mosaic 1), (b) single cropping each year (Mosaic 2) and (c) rain-fed cropland (Mosaic 3) - used in this study. The distributions are indicated in black.

from rivers. By taking this situation into consideration, our calculation scheme was based on the assumption that water is primarily abstracted from rivers (Hanasaki et al., 2010). Through evaluation of IWCR under restrictions of riverine water availability, we estimated the extent to which humidity biases affect hydrological variables that are not determined only from meteorological conditions.

\subsection{Evapotranspiration calculation scheme}

Various formulae for estimating potential evapotranspiration have been developed (e.g., Shelton, 2009), and researchers have utilized suitable formulae for their own research purposes. These formulae are classified into two basic categories: physical and empirical formulae. The former describe potential evapotranspiration from the viewpoint of the energy balance at the land surface, and such formulae are suitable for (micro)meteorological studies requiring a high temporal resolution. Thus, this type of formula requires several meteorological elements such as the surface temperature, humidity, radiation and wind speed. On the other hand, the latter describe climatological conditions for less time-varying phenomena in a simplified manner and, in general, require only two or three meteorological elements. Thus, the latter are suitable for sites where meteorological observation data are limited. Examples of evapotranspiration formulae are given in the Appendix.

The calculation scheme for potential evapotranspiration $E_{\text {pot }}$ employed in H08 is the bulk formula (Kondo, 1994)

$E_{\text {pot }}=\rho C_{\mathrm{D}} U\left(q_{\mathrm{sat}}\left(T_{\mathrm{s}}\right)-q\right)$,

where $\rho, C_{\mathrm{D}}$ and $U$ are the air density, bulk transfer coefficient (0.003) and wind speed, respectively. Thus, $E_{\mathrm{pot}}$ is proportional to the difference between the saturated specific humidity at the surface temperature $q_{\mathrm{sat}}\left(T_{\mathrm{s}}\right)$ and the specific humidity of the air $q$. Since bias correction was independently applied to each meteorological element except for the relative humidity, the physical consistency among meteorological elements guaranteed in the original GCMs might be lost. In this study, we recalculated $q$ to maintain local physical consistency between the bias-corrected temperature and uncorrected relative humidity.

Actual evapotranspiration is estimated by multiplying by a function of the soil water content $W$. If $W$ is less than threequarters of the field capacity $W_{\mathrm{fc}}, E_{\text {act }}$ linearly decreases with decreasing $W$ :

$E_{\mathrm{act}}=\beta E_{\mathrm{pot}}$,

where

$\beta=\left\{\begin{array}{ll}1 & \left(W \geq 0.75 W_{\mathrm{fc}}\right) \\ \frac{W}{0.75 W_{\mathrm{fc}}} & \left(W<0.75 W_{\mathrm{fc}}\right)\end{array}\right.$.

The soil water content in irrigated cropland was assumed to be maintained at $0.75 W_{\mathrm{fc}}$ ( $W_{\mathrm{fc}}$ for rice) to prevent crops from suffering water stress. That is, evapotranspiration from irrigated cropland is not suppressed by a decrease in the soil water content (i.e., $E_{\mathrm{act}}=E_{\mathrm{pot}}$ ) during the growing season. Although the actual threshold may be different for different types of irrigation (e.g., sprinklers, drip irrigation, ditch irrigation) or irrigation management, global information on such variation is unavailable. The adopted irrigation scheme based on the soil water content is simple but applicable for globalscale simulations (e.g., Döll and Siebert, 2002). 


\subsection{Experiment design of this study}

To investigate the effects of bias correction of the humidity, we designed three sets of experiments in this study: (1) a reference experiment, (2) a sensitivity experiment and (3) a bias-corrected experiment. In the reference experiment, a hydrological simulation was performed with the uncorrected humidity data described in Sect. 2.1. We evaluated the evapotranspiration and irrigation water for both present and future periods. The results were also used as a reference for the other two sets of experiments, details of which are given below.

\subsubsection{Sensitivity experiment with hypothetical bias in humidity}

Measurement of the atmospheric humidity inevitably involves errors. Observation-based humidity data sets, which are often used as reference data for bias correction, might contain a certain level of error. Moreover, the sensitivity of the amount of irrigation water to atmospheric humidity varies geographically or seasonally because irrigation water depends not only on meteorological conditions but also on the areal fraction of irrigated cropland, irrigation management, irrigation techniques and the cultivation maneuver (crop type, crop calendar, etc.) in each land cell.

To evaluate the sensitivity of the amount of irrigation water to atmospheric humidity, we carried out a sensitivity experiment in which we introduced a pair of constant biases so that the data were higher and lower than the original GCMbased humidity data and investigated the effect of the biases on irrigation water. The sensitivity is also helpful for predicting the size of the error in the simulation of irrigation water. In this experiment, we introduced "hypothetical" biases into the relative humidity by simply adding biases of $\pm 5 \% \mathrm{RH}$ as a worst case (discussed below) homogeneously to all the land cells. (Hereafter, to discriminate between the unit of relative humidity and a general percentage, we use $\% \mathrm{RH}$ for the unit of humidity.) When the relative humidity exceeded $100 \% \mathrm{RH}$ or became negative, we used values of 100 and $0 \% \mathrm{RH}$, respectively. The other meteorological elements were unchanged. This experiment was carried out for the both present and future periods.

In fact, Willett et al. (2013) reported that the maximum uncertainties in humidity measurements with dry- and wet-bulb thermometers amounted to 2.75 and $5 \% \mathrm{RH}$ at temperatures of 0 and $-10^{\circ} \mathrm{C}$, respectively. Emeis (2010) summarized the errors for various measurement equipment: for example, advanced equipment based on the capacitive method has an accuracy of $2 \% \mathrm{RH}$ (for a humidity of $10-80 \% \mathrm{RH}$ ) to $3 \% \mathrm{RH}$ (for a humidity of 80-ca. 100\% RH). By considering these reports, we set $\pm 5 \% \mathrm{RH}$ as the worst case in this study.

Through such sensitivity experiments, we are able to estimate the largest possible ranges of uncertainty in irrigation water consumption due to an uncertainty in the relative hu- midity of $\alpha \% \mathrm{RH}$ because the uncertainty for irrigation water in the case of geographically random biases within $\pm \alpha \% \mathrm{RH}$ necessarily lies between those for the two extremes of the globally homogeneous bias of $\pm \alpha \%$ RH. Recall that, because of the supply of irrigation water, $E_{\text {act }}=E_{\text {pot }}$ for irrigated cropland during the growing season. If we artificially add positive (negative) biases to the relative humidity without changing other elements, both $\rho$ and $q_{\text {sat }}\left(T_{\mathrm{S}}\right)-q$ on the right-hand side of the bulk formula (Eq. 1) will decrease (increase), resulting in a decrease (increase) in potential evapotranspiration. The increase in $E_{\text {pot }}$ via $q_{\mathrm{sat}}\left(T_{\mathrm{s}}\right)^{1}$ is smaller than the direct decrease in $E_{\text {pot }}$ resulting from introducing a hypothetical bias of $\alpha \% \mathrm{RH}$. Therefore, $E_{\text {act }}$ has a monotonic dependence on the humidity bias: $E_{\text {act }}$ becomes smaller (larger) for positive (negative) biases in the relative humidity.

We note that this simple relation holds only for irrigated cropland during the crop-growing season when irrigation water is limitlessly supplied. In rain-fed cropland or irrigation-free seasons, evapotranspiration has a complex dependence on meteorological conditions (Wang and Dickinson, 2012) because $E_{\text {act }}$ also depends on the soil moisture content (Eq. 3).

The sensitivity experiment was also carried out for a future period because different GCMs project different future climates. Even if the biases in meteorological elements were completely removed for the present period, the future temperature or precipitation would still differ across the GCMs. Since evapotranspiration is also sensitive to temperature conditions, the future sensitivity may be different from the present sensitivity and also vary among the GCMs. The sensitivity experiment for a future period will help clarify the propagation of humidity biases into the amount of irrigation water even under different future climates projected by different GCMs.

\subsubsection{Bias-corrected experiment}

If we introduce bias correction of the humidity, does it affect hydrological projections and have any advantages? To examine this effect, we prepared another set of meteorological data for which the humidity data were bias-corrected with a primitive methodology that adjusts only the monthly climatology. Using this bias-corrected humidity data set and the original bias-corrected meteorological data sets for the other elements, we recalculated the hydrological process in the same way and compared the results with the uncorrected ones (i.e., those of the reference experiment). This experiment was carried out for both the present and future periods.

The bias correction methodology was based on additive adjustment in order to preserve the range of variability in the

\footnotetext{
${ }^{1} \mathrm{~A}$ decrease (increase) in potential evapotranspiration will increase (decrease) $T_{\mathrm{S}}$ owing to the prevention (promotion) of cooling by latent heat, and result in an increase (decrease) in $E_{\text {pot }}$ through an increase (decrease) in $q_{\mathrm{sat}}\left(T_{\mathrm{S}}\right)$.
} 
Table 2a. Total number of days when the humidity is oversaturated (>100\% RH) in the original regridded GCM data. Both the annual and seasonal sums are given as the mean over all land cells (67 420 cells). The total numbers of days are given in parentheses in the header.

\begin{tabular}{|c|c|c|c|c|c|c|c|c|c|c|}
\hline \multirow[t]{2}{*}{ GCMs } & \multicolumn{5}{|c|}{ 1971-2000 } & \multicolumn{5}{|c|}{ 2070-2099 RCP8.5 } \\
\hline & $\begin{array}{r}\text { Annual } \\
\text { (10958) }\end{array}$ & $\begin{array}{r}\text { DJF } \\
(2708)\end{array}$ & $\begin{array}{l}\text { MAM } \\
(2760)\end{array}$ & $\begin{array}{r}\text { JJA } \\
(2760)\end{array}$ & $\begin{array}{r}\text { SON } \\
(2730)\end{array}$ & $\begin{array}{r}\text { Annual } \\
(10957)\end{array}$ & $\begin{array}{r}\text { DJF } \\
(2707)\end{array}$ & $\begin{array}{l}\text { MAM } \\
(2760)\end{array}$ & $\begin{array}{r}\text { JJA } \\
(2760)\end{array}$ & $\begin{array}{r}\text { SON } \\
(2730)\end{array}$ \\
\hline GFDL-ESM2M & 715.6 & 330.4 & 99.0 & 20.8 & 265.5 & 692.4 & 342.5 & 87.9 & 27.9 & 234.1 \\
\hline HadGEM2-ES & 738.6 & 416.1 & 165.5 & 10.1 & 146.9 & 417.8 & 263.7 & 78.9 & 3.1 & 72.2 \\
\hline IPSL-CM5A-LR & 0.0 & 0.0 & 0.0 & 0.0 & 0.0 & 0.0 & 0.0 & 0.0 & 0.0 & 0.0 \\
\hline MIROC-ESM-CHEM & 636.8 & 310.9 & 187.9 & 14.6 & 123.3 & 228.5 & 122.7 & 62.8 & 12.8 & 30.2 \\
\hline NorESM1-M & 290.9 & 169.7 & 48.7 & 0.5 & 72.0 & 130.0 & 91.7 & 20.5 & 0.8 & 16.8 \\
\hline Ensemble mean & 476.4 & 245.4 & 100.2 & 9.2 & 121.5 & 293.7 & 164.1 & 50.0 & 8.9 & 70.7 \\
\hline
\end{tabular}

Table $\mathbf{2 b}$. Total number of days when the humidity is truncated at $100 \% \mathrm{RH}$ during adjustment by our primitive bias correction described in Sect. 2.4.2. Both the annual and seasonal sums are given by the mean over all land cells ( 67420 cells). The total numbers of days are given in parentheses in the header.

\begin{tabular}{|c|c|c|c|c|c|c|c|c|c|c|}
\hline \multirow[t]{2}{*}{ GCMs } & \multicolumn{5}{|c|}{ 1971-2000 } & \multicolumn{5}{|c|}{ 2070-2099 RCP8.5 } \\
\hline & $\begin{array}{r}\text { Annual } \\
\text { (10958) }\end{array}$ & $\begin{array}{r}\text { DJF } \\
(2708)\end{array}$ & $\begin{array}{l}\text { MAM } \\
(2760)\end{array}$ & $\begin{array}{r}\text { JJA } \\
(2760)\end{array}$ & $\begin{array}{r}\text { SON } \\
(2730)\end{array}$ & $\begin{array}{c}\text { Annual } \\
(10957)\end{array}$ & $\begin{array}{r}\text { DJF } \\
(2707)\end{array}$ & $\begin{array}{l}\text { MAM } \\
(2760)\end{array}$ & $\begin{array}{r}\text { JJA } \\
(2760)\end{array}$ & $\begin{array}{r}\text { SON } \\
(2730)\end{array}$ \\
\hline GFDL-ESM2M & 526.7 & 256.0 & 117.8 & 37.5 & 115.4 & 563.0 & 280.6 & 115.6 & 49.9 & 116.8 \\
\hline HadGEM2-ES & 528.2 & 313.4 & 89.9 & 11.6 & 113.2 & 333.1 & 202.4 & 52.7 & 10.1 & 67.7 \\
\hline IPSL-CM5A-LR & 186.2 & 92.3 & 32.2 & 27.9 & 33.8 & 141.0 & 72.5 & 24.3 & 20.9 & 23.3 \\
\hline MIROC-ESM-CHEM & 411.6 & 245.6 & 74.5 & 7.3 & 84.3 & 170.5 & 99.4 & 27.8 & 10.7 & 32.5 \\
\hline NorESM1-M & 277.2 & 167.2 & 41.8 & 10.0 & 58.2 & 159.9 & 103.9 & 23.7 & 7.9 & 24.3 \\
\hline Ensemble mean & 386.0 & 214.9 & 71.2 & 18.9 & 81.0 & 273.5 & 151.8 & 48.8 & 19.9 & 52.9 \\
\hline
\end{tabular}

relative humidity because the evapotranspiration obtained by a physical formula (see Appendix) is sensitive to the vapor pressure deficit. First, we obtained the monthly climatological relative humidity at all land cells for each GCM by averaging the relative humidity data for the same month of the year over the period 1960-1999. By subtracting the monthly climatological relative humidity in the GCM for the same period from those in the WATCH observational data, we determined the climatological monthly adjustments. Then, we compiled daily bias-corrected humidity data by simply adding the climatological monthly adjustments to the original GCM daily humidity data. Values of less than $0 \% \mathrm{RH}$ and greater than $100 \% \mathrm{RH}$ were set to 0 and $100 \% \mathrm{RH}$, respectively.

We summarize the statistics of the truncated humidity data before and during our bias correction in Table 2. The original regridded data already contain supersaturation (greater than $100 \%$ RH), except for IPSL (Table 2a). Most of the supersaturation data were obtained at high northern latitudes in winter where the atmospheric temperature was well below $0{ }^{\circ} \mathrm{C}$. The number of truncated humidity data at $100 \% \mathrm{RH}$ during our primitive bias correction (Table $2 b$ ) is less than the number of supersaturation data in the original regridded data except for IPSL, particularly in the boreal winter, because a certain proportion of the oversaturated data in the GCMs were adjusted to undersaturated data by the bias correction when the monthly climatological humidity of the GCMs was larger than that of the WATCH data. In contrast, the number of truncated humidity data at $0 \% \mathrm{RH}$ is very small (Table 2c). These truncations were observed in highly dry regions, such as deserts. Generally, the number of truncated data at $100 \% \mathrm{RH}$ in the future projection (RCP8.5) is smaller than that in the present, whereas the number at $0 \% \mathrm{RH}$ is larger than the present number.

We expect the errors in evapotranspiration due to these truncations to be marginal and not to cause major problems in the interpretation of our results on hydrological variables. In fact, the evapotranspiration under the low-temperature conditions typically seen at high northern latitudes in winter approaches zero. Moreover, few crops are cultivated in the winter, and irrigated agriculture is not practiced in these regions. Similarly, evapotranspiration in and around desert areas (except in limited areas with intensive irrigation) is also very small. 
Table 2c. Total number of days when the humidity is truncated at $0 \% \mathrm{RH}$ during adjustment by our primitive bias correction described in Sect. 2.4.2. Both the annual and seasonal sums are given by the mean over all land cells (67 420 cells). The total numbers of days are given in parentheses in the header.

\begin{tabular}{|c|c|c|c|c|c|c|c|c|c|c|}
\hline \multirow[t]{2}{*}{ GCMs } & \multicolumn{5}{|c|}{ 1971-2000 } & \multicolumn{5}{|c|}{ 2070-2099 RCP8.5 } \\
\hline & $\begin{array}{r}\text { Annual } \\
(10958)\end{array}$ & $\begin{array}{r}\text { DJF } \\
(2708)\end{array}$ & $\begin{array}{l}\text { MAM } \\
(2760)\end{array}$ & $\begin{array}{r}\text { JJA } \\
(2760)\end{array}$ & $\begin{array}{r}\text { SON } \\
(2730)\end{array}$ & $\begin{array}{r}\text { Annual } \\
(10957)\end{array}$ & $\begin{array}{r}\text { DJF } \\
(2707)\end{array}$ & $\begin{array}{l}\text { MAM } \\
(2760)\end{array}$ & $\begin{array}{r}\text { JJA } \\
(2760)\end{array}$ & $\begin{array}{r}\text { SON } \\
(2730)\end{array}$ \\
\hline GFDL-ESM2M & 28.34 & 3.19 & 7.53 & 10.42 & 7.20 & 39.35 & 4.25 & 10.25 & 15.35 & 9.51 \\
\hline HadGEM2-ES & 2.34 & 0.11 & 1.34 & 0.38 & 0.49 & 5.20 & 0.39 & 2.56 & 1.31 & 0.95 \\
\hline IPSL-CM5A-LR & 1.03 & 0.04 & 0.61 & 0.19 & 0.19 & 4.94 & 0.74 & 2.50 & 0.80 & 0.90 \\
\hline MIROC-ESM-CHEM & 7.79 & 1.23 & 2.01 & 2.04 & 2.50 & 17.21 & 2.63 & 4.98 & 3.65 & 5.95 \\
\hline NorESM1-M & 10.62 & 2.61 & 3.82 & 2.45 & 1.74 & 18.80 & 2.80 & 9.46 & 4.43 & 2.11 \\
\hline Ensemble mean & 10.02 & 1.44 & 3.06 & 3.10 & 2.42 & 17.10 & 2.16 & 5.95 & 5.11 & 3.88 \\
\hline
\end{tabular}

Table 3. Global average of monthly SD (\% RH) in relative humidity, shown in Fig. 4, for each land use.

\begin{tabular}{lcccc}
\hline GCMs & Mosaic 0 & Mosaic 1 & Mosaic 2 & Mosaic 3 \\
\hline GFDL-ESM2M & 20.3 & 26.2 & 23.9 & 17.6 \\
HadGEM2-ES & 11.7 & 24.3 & 20.1 & 13.4 \\
IPSL-CM5A-LR & 15.0 & 34.8 & 27.0 & 13.6 \\
MIROC-ESM-CHEM & 20.4 & 18.0 & 20.0 & 17.4 \\
NorESM1-M & 17.9 & 20.4 & 18.8 & 13.4 \\
\hline
\end{tabular}

\section{Results}

\subsection{Comparison of performance of meteorological elements between GCMs}

We first examine the differences in the meteorological elements between the five GCMs in the framework of the reference experiment to search for existing GCM-inherent biases and compare them with the WATCH observation-based meteorological elements to evaluate the performance of bias correction. Figure 2 shows the monthly difference worldwide averaged over each type of land use (mosaic). Monthly profiles of the atmospheric temperature, precipitation and shortwave downward radiation for the five GCMs agree with those of WATCH. Note that the 30-year analysis period (19712000) is slightly different from the bias correction period (1960-1999). For the wind speed data, although the monthly profile of MIROC is slightly larger than that of WATCH over Mosaic 1, we consider the overall performance of bias correction to be reasonably good for the wind data.

In contrast, the monthly profiles of the relative humidity, which contain GCM-inherent biases, show a large dispersion between the five GCMs and also deviate from those of WATCH. The global-mean relative humidity over Mosaic 1 shows a larger dispersion than those over the other mosaics: the largest difference in the relative humidity between the monthly GCMs reaches $19.8 \%$ RH in both January and October with a minimum of $11.0 \%$ RH in May for Mosaic 1.

Such differences in the uncorrected relative humidity cause the deviation of the potential evapotranspiration and evapotranspiration between the five GCMs. Figure 3 shows their monthly profiles. Different GCMs have different monthly profiles and peak months. The difference in the potential evapotranspiration among the GCMs for Mosaic 1 reaches a maximum of $1.23 \mathrm{~mm} \mathrm{day}^{-1}$ in June with a minimum of $0.56 \mathrm{~mm} \mathrm{day}^{-1}$ in December. The difference exceeds $0.9 \mathrm{~mm} \mathrm{day}^{-1}$ from March to October. Since the temperature, shortwave downward radiation and wind speed, which are required for the calculation of the potential evapotranspiration (Eq. 1), are successfully bias-corrected (Fig. 2), these differences in the potential evapotranspiration are considered to be mainly due to GCM biases in the relative humidity. NorESM tends to have a small but positive bias of the potential evapotranspiration and a small negative bias of the evapotranspiration during the summer. However, no clear biases of the relative humidity can be observed in Fig. 2 .

Next, we determine the geographical distribution of the GCM biases with respect to the WATCH data because regional deviations with opposite signs may cancel each other when calculating the global mean. Figures 4, 5 and 6 show the SD of 12-month climatological data of the relative humidity, atmospheric temperature and precipitation of the GCMs with respect to the WATCH data, respectively. Strong regional patterns were detected in the relative humidity (Fig. 4). Figure 4 also shows that the relative humidity in high mountainous areas (Rocky Mountains, Andes and Himalayas) have larger deviations from the WATCH data for all GCMs. Each GCM has a different geographical distribution. For example, GFDL exhibits large differences over the 

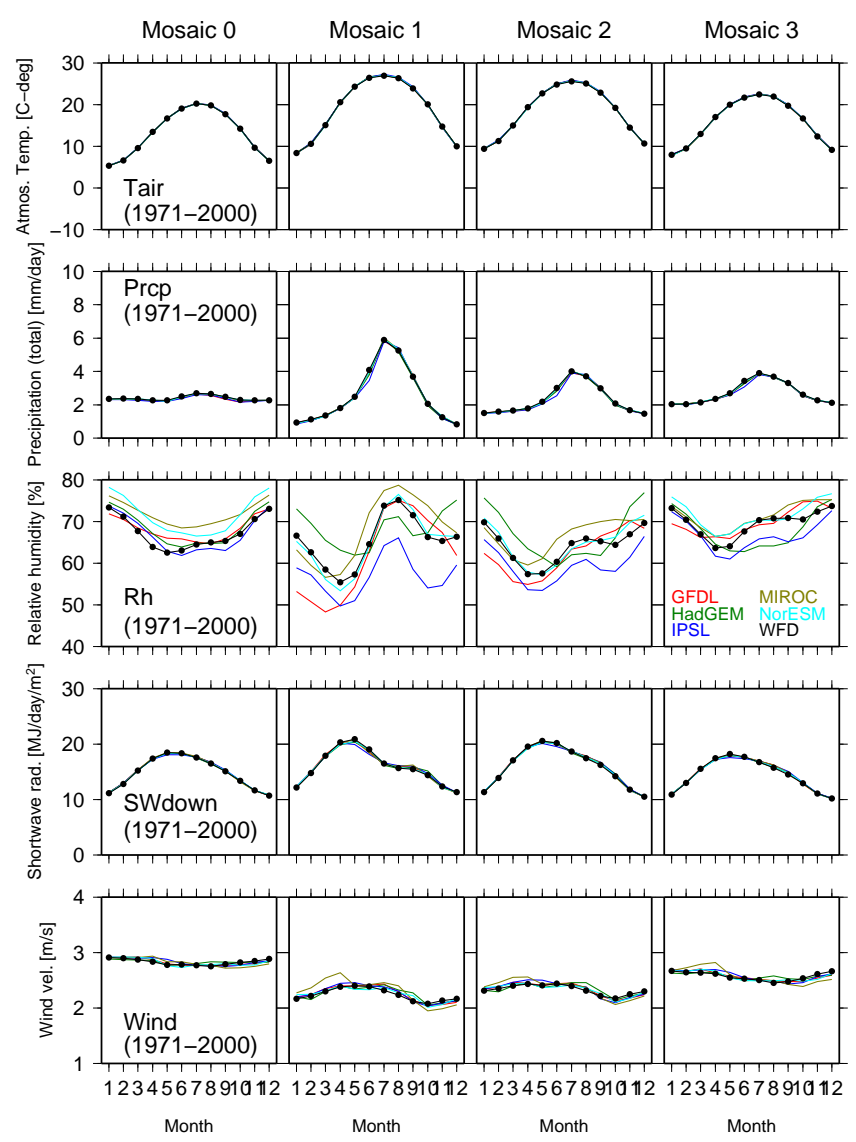

Figure 2. Monthly profiles of meteorological elements used in this study for 1971-2000. The results are aggregated over each type of land use, identified by the mosaic number. Profiles of the five GCMs are indicated in different colors: (red) GFDL, (green) HadGEM, (blue) IPSL, (dark yellow) MIROC and (light blue) NorESM. Profiles of the WATCH data are shown as black lines with dots.

world. HadGEM and IPSL have large differences in Eurasia but good performance in Australia. MIROC has high deviations in inland regions of Asia and Australia. NorESM has small differences in Europe and the eastern United States but large differences in Australia.

In contrast, uniformly distributed small biases (less than $0.5^{\circ} \mathrm{C}$ for most of the world) were observed for the temperature (Fig. 5). The SD for the precipitation (Fig. 6) is less than $0.2 \mathrm{mmday}^{-1}$ for most of the world and around $0.5 \mathrm{~mm} \mathrm{day}^{-1}$ for humid areas (e.g., Southeast Asia). Although exceptions are seen in the Amazonian inland, where a large SD is observed for GFDL and IPSL, these contributions are considered to be marginal when taking the large annual precipitation (greater than $2000 \mathrm{~mm}$ ) and the smaller amount of cropland (see Fig. 1) into account. These results also indicate that the bias corrections of the atmospheric temperature and precipitation were successful at the regional scale.

We averaged the monthly SD over the land cells of each mosaic and summarized the results in Table 3. HadGEM has the smallest deviation from WATCH over all land cells (Mosaic 0). However, MIROC and NorESM have superior performance for Mosaic 1 and 2. Since both Mosaic 1 and 2 are irrigated cropland, differences in the potential evapotranspiration directly affect differences in the amount of irrigation water. Errors in the humidity are one possible error source when calculating evapotranspiration. In this sense, small humidity biases over irrigated cropland are beneficial for suppressing their effects on irrigation water provided that other meteorological elements are successfully bias-corrected.

\subsection{GCM features and their propagation into future projections}

Next, we examine the extent to which GCM-inherent features in the relative humidity affect the estimation of irrigation water and propagate into a future period (2070-2099) in the framework of the reference experiment. If the effects are not negligible, bias correction of the humidity, as well as other meteorological elements, is highly recommended.

Figure 7 shows future monthly profiles of the five GCMs. Since the meteorological variables are bias-corrected for 1960-1999, the GCM-inherent future climate trends diverge from their monthly profiles. The monthly profiles of the atmospheric temperature and precipitation show small differences but have similar shapes across the GCMs. Shortwave downward radiation and wind have little dispersion among the GCMs. In contrast, the relative humidity has large dispersion among the GCMs. For each GCM, in comparison with Fig. 2, the monthly profiles of the relative humidity for the present and future periods have similar shapes.

To easily perceive the differences between the GCMs, we evaluate the relative anomaly of the five GCMs with respect to their ensemble mean. The results of anomalies in the relative humidity and related hydrological elements (potential evapotranspiration, evapotranspiration, IWD and IWCR) are shown in Figs. 8 and 9.

First, Fig. 8 shows that the monthly anomaly profiles of the potential evapotranspiration, evapotranspiration and IWD are similar but vertically opposite those of the relative humidity. This relation is expected from Eq. (1), while other meteorological conditions are fixed. We note that although the evapotranspiration from rain-fed cropland (Mosaic 3) also depends on the soil moisture, GCM-inherent features are weakly observed in the monthly profile of evapotranspiration.

Second, Fig. 9 shows that the future monthly anomaly profiles of the relative humidity are very similar to the present ones (Fig. 8) for all GCMs. This implies that the GCMinherent biases propagate into future projections. As a result, the future monthly profiles of other hydrological elements also resemble the present ones.

Since IWCR is limited by the availability of riverine water, GCM-inherent features are weakened but remain. For example, larger positive anomalies in HadGEM and IPSL and negative ones in MIROC during boreal fall for 1971- 


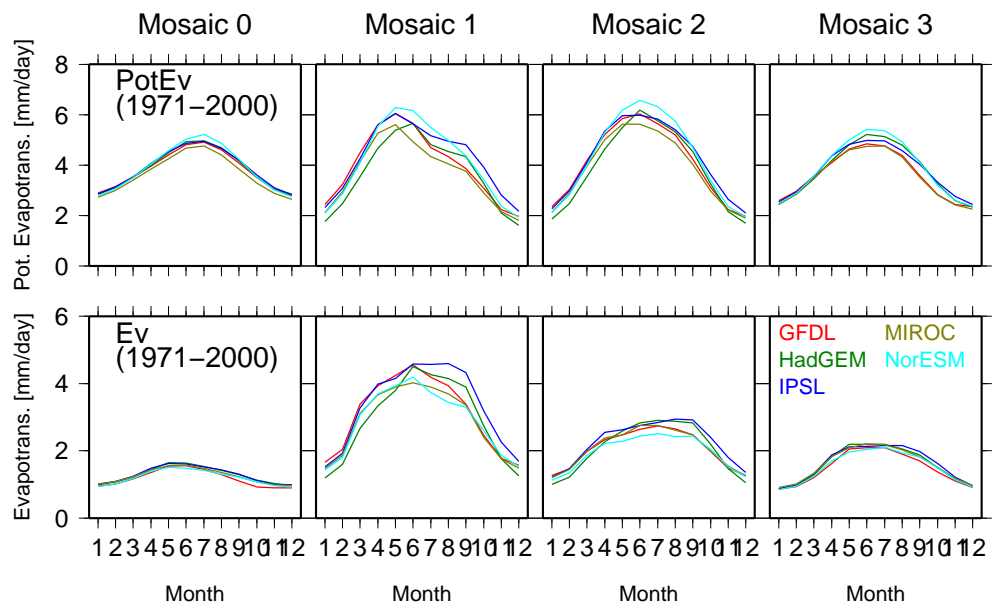

Figure 3. Monthly profiles of the potential evapotranspiration and evapotranspiration for 1971-2000 calculated in this study. The results are aggregated over the same land use. Profiles of the five GCMs are indicated in different colors: (red) GFDL, (green) HadGEM, (blue) IPSL, (dark yellow) MIROC and (light blue) NorESM.
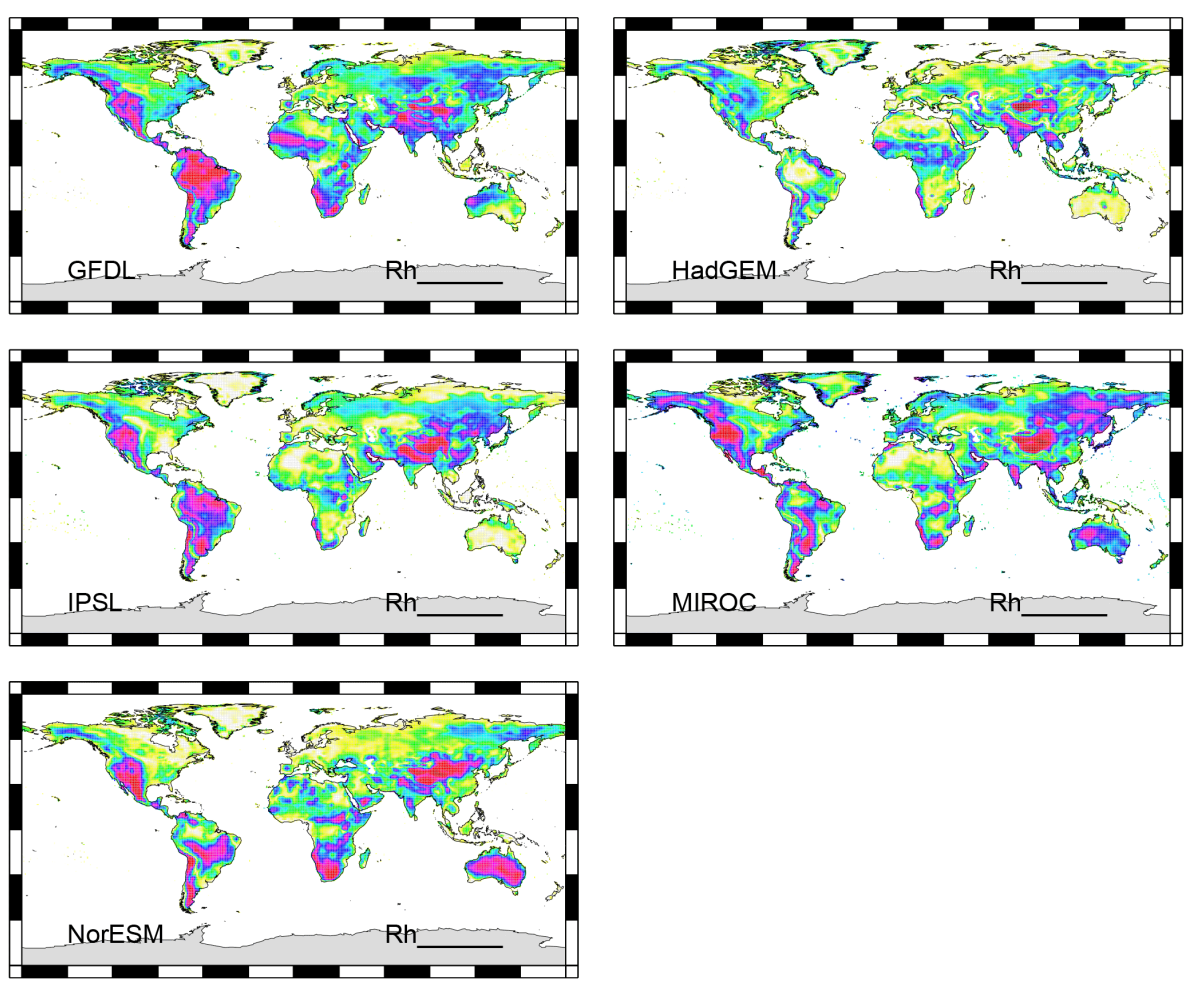

$\begin{array}{lllllllll}0.0 & 2.5 & 5.0 & 7.5 & 10.0 & 15.0 & 20.0 & 30.0 & 100.0\end{array}$

SD (12 monthly RH) [\%]

Figure 4. Geographical distribution of the SD from the WATCH data for the relative humidity. The SD was evaluated from 12-month climatological (1971-2000) data for each land cell.

2000 (Fig. 8) are similarly observed in the future projections (Fig. 9).

Geographical distribution of the monthly anomaly of the relative humidity (Fig. 10) also shows that GCM-inherent biases are propagated into future projections. For all GCMs, the anomaly pattern for the future periods resembles that for 1971-2000. The results imply that, if we adequately remove the GCM-inherent biases of the humidity, their propagation into future projections can be alleviated. 


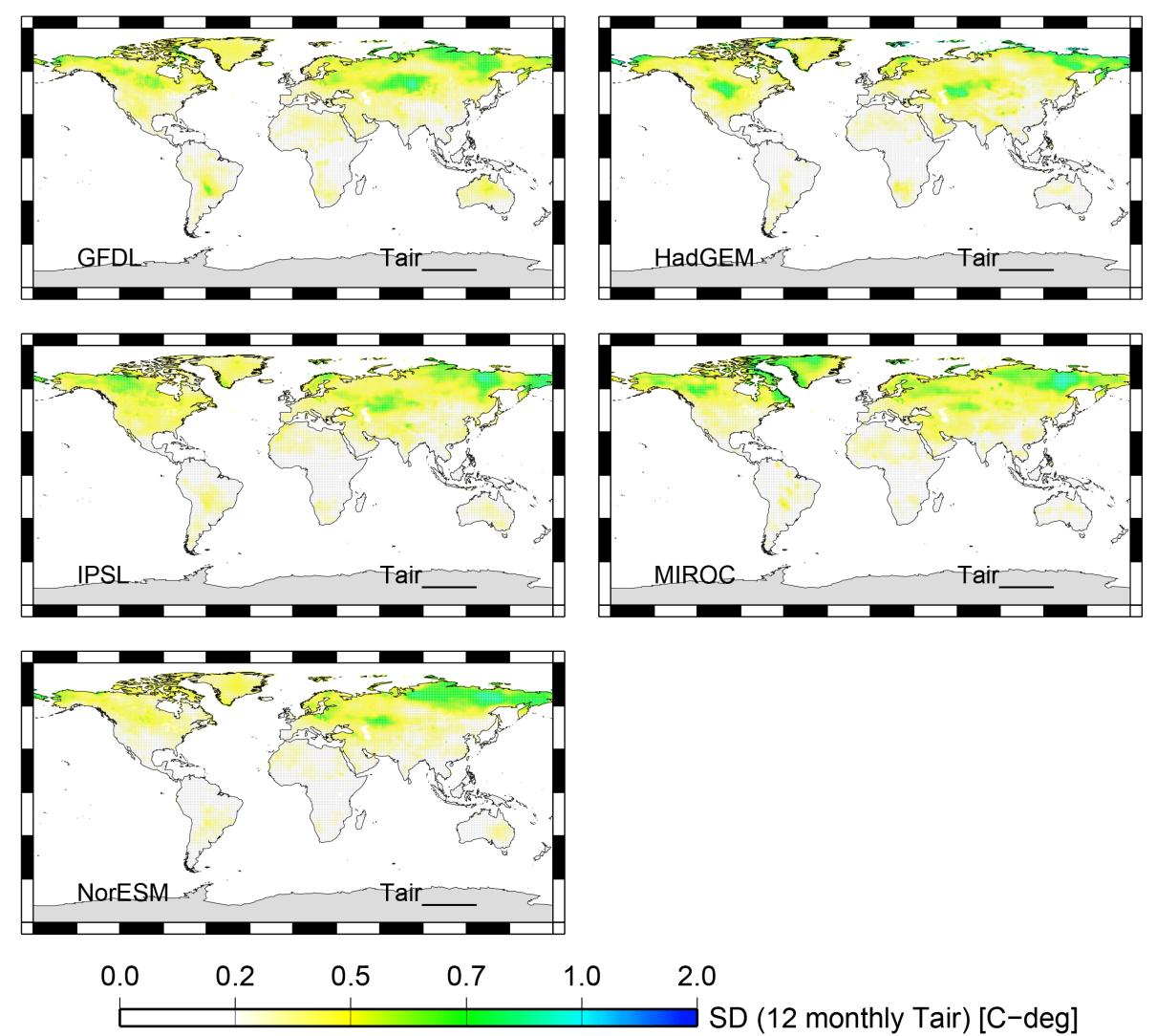

Figure 5. Same as Fig. 4 but for the atmospheric temperature.

Table 4a. Results of the present (1971-2000) estimation and future (2070-2099) projection of irrigation water demand (IWD). The values in parentheses are changes (\%) relative to the present values. The range (the difference between the maximum and minimum) of the five GCMs is given in the bottom line.

\begin{tabular}{|c|c|c|c|c|c|c|c|c|c|}
\hline \multirow{5}{*}{$\begin{array}{l}\text { GCMs } \\
\text { GFDL-ESM2M }\end{array}$} & \multicolumn{7}{|c|}{ Global sum of IWD $\left(\mathrm{km}^{3} \mathrm{yr}^{-1}\right)$ and relative change $(\%)$} & & \\
\hline & \multirow{4}{*}{$\begin{array}{r}\text { present } \\
(1971-2000)\end{array}$} & \multirow{2}{*}{\multicolumn{6}{|c|}{$\begin{array}{l}\text { Mosaic 0 } \\
\text { future (2070-2099) }\end{array}$}} & & \\
\hline & & & & & & & & & \\
\hline & & \multicolumn{2}{|c|}{ RCP2.6 } & \multicolumn{2}{|c|}{$\mathrm{RCP} 4.5$} & \multicolumn{2}{|c|}{ RCP6.0 } & \multicolumn{2}{|c|}{ RCP8.5 } \\
\hline & & 1425.4 & $(+7.60)$ & 1426.9 & $(+7.71)$ & 1485.1 & $(+12.11)$ & 1569.7 & $(+18.49)$ \\
\hline HadGEM2-ES & 1295.1 & 1289.5 & $(-0.43)$ & 1370.9 & $(+5.85)$ & 1345.7 & $(+3.90)$ & 1435.7 & $(+10.85)$ \\
\hline IPSL-CM5A-LR & 1435.5 & 1484.5 & $(+3.41)$ & 1507.7 & $(+5.03)$ & 1585.4 & $(+10.44)$ & 1703.7 & $(+18.68)$ \\
\hline MIROC-ESM-CHEM & 1161.3 & 1265.4 & $(+8.96)$ & 1249.4 & $(+7.59)$ & 1389.1 & $(+19.61)$ & 1377.0 & $(+18.57)$ \\
\hline NorESM1-M & 1152.6 & 1182.2 & $(+2.56)$ & 1211.4 & $(+5.10)$ & 1238.1 & $(+7.41)$ & 1322.6 & $(+14.75)$ \\
\hline Ensemble mean & 1273.8 & 1329.4 & $(+4.36)$ & 1353.3 & $(+6.24)$ & 1408.7 & $(+10.59)$ & 1481.7 & $(+16.32)$ \\
\hline Range & 282.9 & 302.3 & & 296.3 & & 347.3 & & 381.1 & \\
\hline
\end{tabular}

\subsection{Uncertainties in absolute values of irrigation water across GCMs}

In Table 4, we summarize the results of the reference experiment on present and future values of the global sum of irrigation water, focusing on their ranges across the GCMs. Note that the global sum of irrigation water (Mosaic 0) is equivalent to the sum of those for Mosaic 1 and 2 because no irrigation is applied to Mosaic 3. IWD (Table 4a) ranges be- tween 1152.6 and $1435.5 \mathrm{~km}^{3} \mathrm{yr}^{-1}$ for 1971-2000. A larger increase of ca. $20 \%$ in the future (2070-2099) is projected under a higher concentration of greenhouse gases such as under RCP8.5. Both absolute values and relative changes show a large dispersion between the GCMs.

Since it is difficult to validate these results with observed data because of the lack of global census data, we compare the results with those in previous studies. Wada et al. 


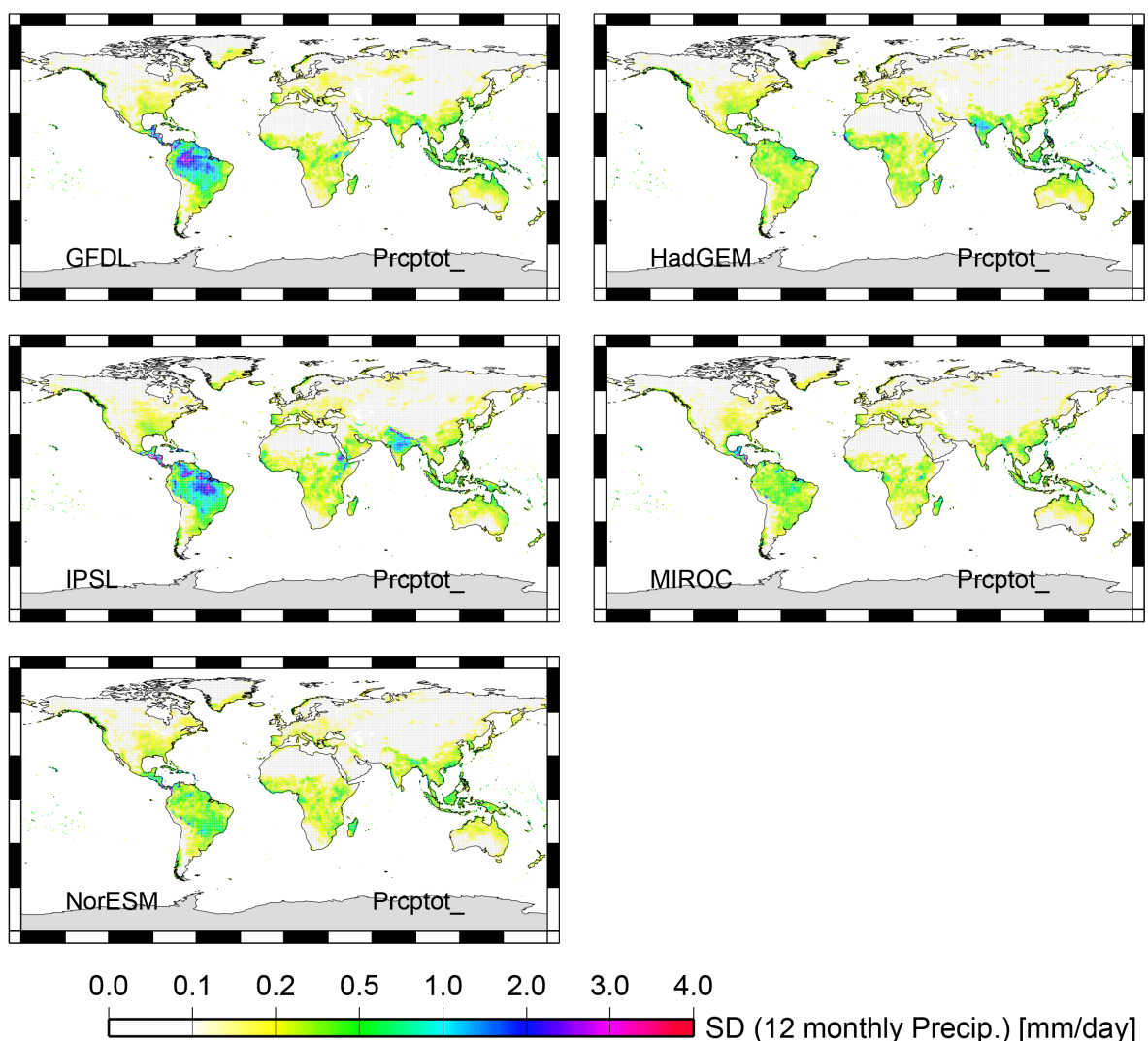

Figure 6. Same as Fig. 4 but for the precipitation.

Table 4b. Results of the present (1971-2000) estimation and future (2070-2099) projection of irrigation water consumption from rivers (IWCR). The values in parentheses are changes (\%) relative to the present values. The range (the difference between the maximum and minimum) of the five GCMs is given in the bottom line.

\begin{tabular}{|c|c|c|c|c|c|c|c|c|c|}
\hline \multirow{4}{*}{ GCMs } & \multicolumn{9}{|c|}{ Global sum of IWCR $\left(\mathrm{km}^{3} \mathrm{yr}^{-1}\right)$ and relative change (\%) } \\
\hline & \multirow{3}{*}{$\begin{array}{r}\text { present } \\
(1971-2000)\end{array}$} & \multirow{2}{*}{\multicolumn{8}{|c|}{$\begin{array}{l}\text { Mosaic 0 } \\
\quad \text { future (2070-2099) }\end{array}$}} \\
\hline & & & & & & & & & \\
\hline & & \multicolumn{2}{|c|}{$\mathrm{RCP} 2.6$} & \multicolumn{2}{|c|}{$\mathrm{RCP} 4.5$} & \multicolumn{2}{|c|}{ RCP6.0 } & \multicolumn{2}{|c|}{ RCP8.5 } \\
\hline GFDL-ESM2M & 522.5 & 525.1 & $(+0.49)$ & 526.9 & $(+0.83)$ & 527.9 & $(+1.02)$ & 540.0 & $(+3.35)$ \\
\hline HadGEM2-ES & 524.9 & 515.7 & $(-1.75)$ & 522.8 & $(-0.39)$ & 518.4 & $(-1.23)$ & 532.0 & $(+1.35)$ \\
\hline IPSL-CM5A-LR & 551.4 & 542.4 & $(-1.62)$ & 542.7 & $(-1.57)$ & 539.6 & $(-2.13)$ & 550.5 & $(-0.15)$ \\
\hline MIROC-ESM-CHEM & 511.6 & 513.5 & $(+0.36)$ & 507.4 & $(-0.83)$ & 519.0 & $(+1.44)$ & 506.0 & $(-1.10)$ \\
\hline NorESM1-M & 497.7 & 500.3 & $(+0.53)$ & 502.6 & $(+0.99)$ & 507.3 & $(+1.93)$ & 514.4 & $(+3.36)$ \\
\hline Ensemble mean & 521.6 & 519.4 & $(-0.42)$ & 520.5 & $(-0.21)$ & 522.4 & $(+0.15)$ & 528.6 & $(+1.34)$ \\
\hline Range & 53.7 & 42.1 & & 40.1 & & 32.3 & & 44.5 & \\
\hline
\end{tabular}

(2013) reviewed past studies on irrigation water consumption (in their Table S1), which was in the range of 1029$1772 \mathrm{~km}^{3} \mathrm{yr}^{-1}$ at the end (or the last few decades) of the 20th century. Rost et al. (2008) reported that global blue water consumption for irrigation use was $1364 \mathrm{~km}^{3} \mathrm{yr}^{-1}$. Our estimations of IWD are close to these reported results.

In contrast to IWD, future changes in IWCR (Table 4b) relative to the 1971-2000 values show a small increase of at most $3.4 \%$. Several pairs of GCM-RCPs show a small decrease in the future. Since IWCR is strongly constrained by water availability from rivers, these results reflect the future river flow. In other words, current irrigation maneuvers cannot be sustained by only riverine water under a future warming climate for these scenarios because, despite increasing demand for irrigation water (Table $4 a$ ), water consumption 

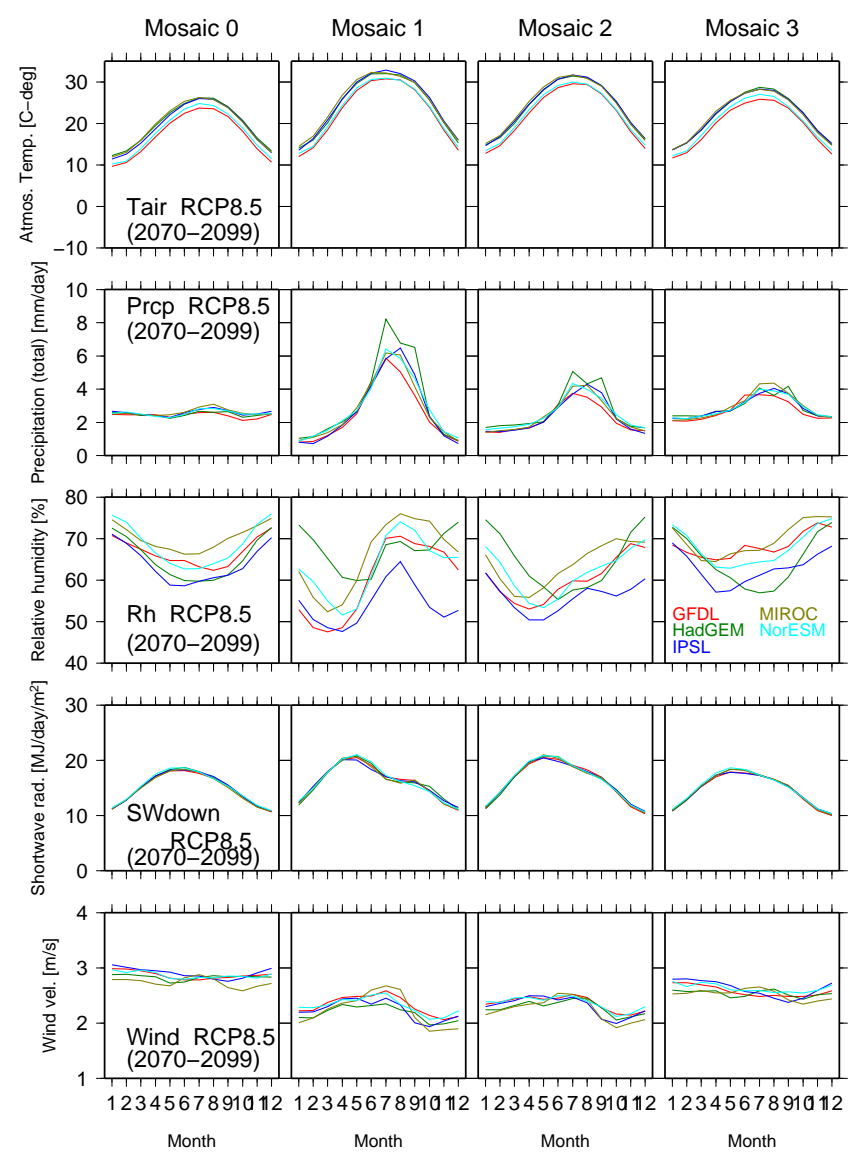

Figure 7. Monthly profiles of meteorological elements used in this study for 2070-2099 under RCP8.5. The results are aggregated over each type of land use, identified by the mosaic number. Profiles of the five GCMs are indicated in different colors: (red) GFDL, (green) HadGEM, (blue) IPSL, (dark yellow) MIROC and (light blue) NorESM.

that can be supplied from rivers cannot meet the demand (Table $4 \mathrm{~b}$ ) at the global scale.

We note that MIROC and NorESM, whose relative humidity shows small deviations from the observation (see Sect. 3.1), tend to have the smallest IWD and IWCR values among the five GCMs.

Monthly profiles of the global sum of the present and future IWCR (Fig. 11) differ among the GCMs. Since most irrigated croplands are distributed in the Northern Hemisphere, the global sum of IWCR has a peak in boreal summer of approximately 3 times the value in boreal winter. Despite large differences in the absolute monthly values between the GCMs, all GCMs show a future increase in IWCR in boreal summer and a decrease in boreal spring under a future warmer climate. Although in April the global sum of the future IWD is approximately the same as that of the present IWD (not shown), the future IWCR is expected to decrease in boreal spring (Fig. 11). This result indicates that the future decrease in IWCR is attributable to a deficit in irrigation

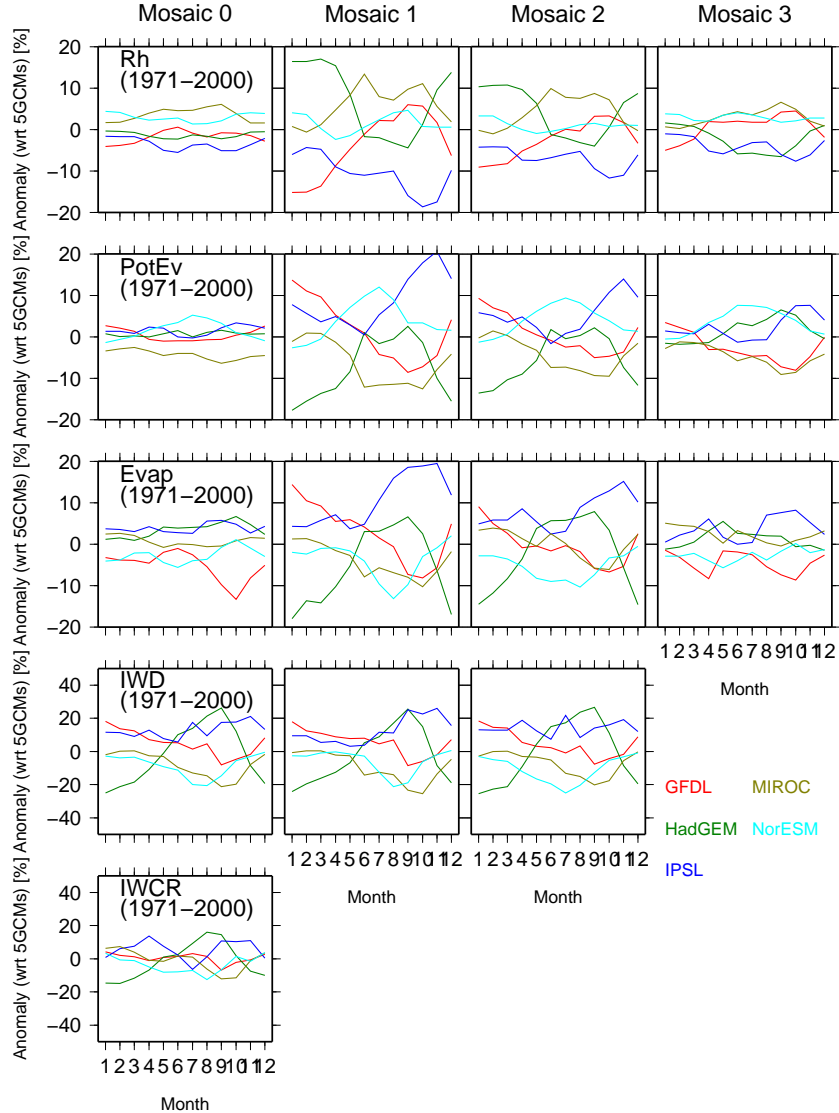

Figure 8. Monthly anomalies with respect to the ensemble mean of five GCMs for 1971-2000. The results are aggregated over each land use. The anomaly in each GCM is indicated in different colors: (red) GFDL, (green) HadGEM, (blue) IPSL, (dark yellow) MIROC and (light blue) NorESM. The panels from top to bottom show the relative humidity, potential evapotranspiration, evapotranspiration, irrigation water demand (IWD) and irrigation water consumption from rivers (IWCR).

water that can be supplied from rivers, not to an increase in evapotranspiration demand from cropland.

\subsection{Sensitivity experiment with hypothetical biases}

\subsubsection{Present period (1971-2000)}

We investigate the effect of humidity biases on irrigation water by examining the results of the sensitivity experiment by adding biases of $\pm 5 \%$ RH homogeneously all over the world. Table 5 shows that biases of $\pm 5 \%$ RH approximately correspond to changes in IWD of \pm 6.5 to $\pm 7.5 \%$ and IWCR of \pm 3.5 to $\pm 5.0 \%$ as the maximum error range. Monthly profiles of IWCR with biased humidity also deviate from the original profiles (Fig. 12). The effect of the artificial bias is clearly observed during boreal summer. In the comparison of Tables 4 and 5 or Figs. 11 and 12, changes with $\pm 5 \%$ RH 


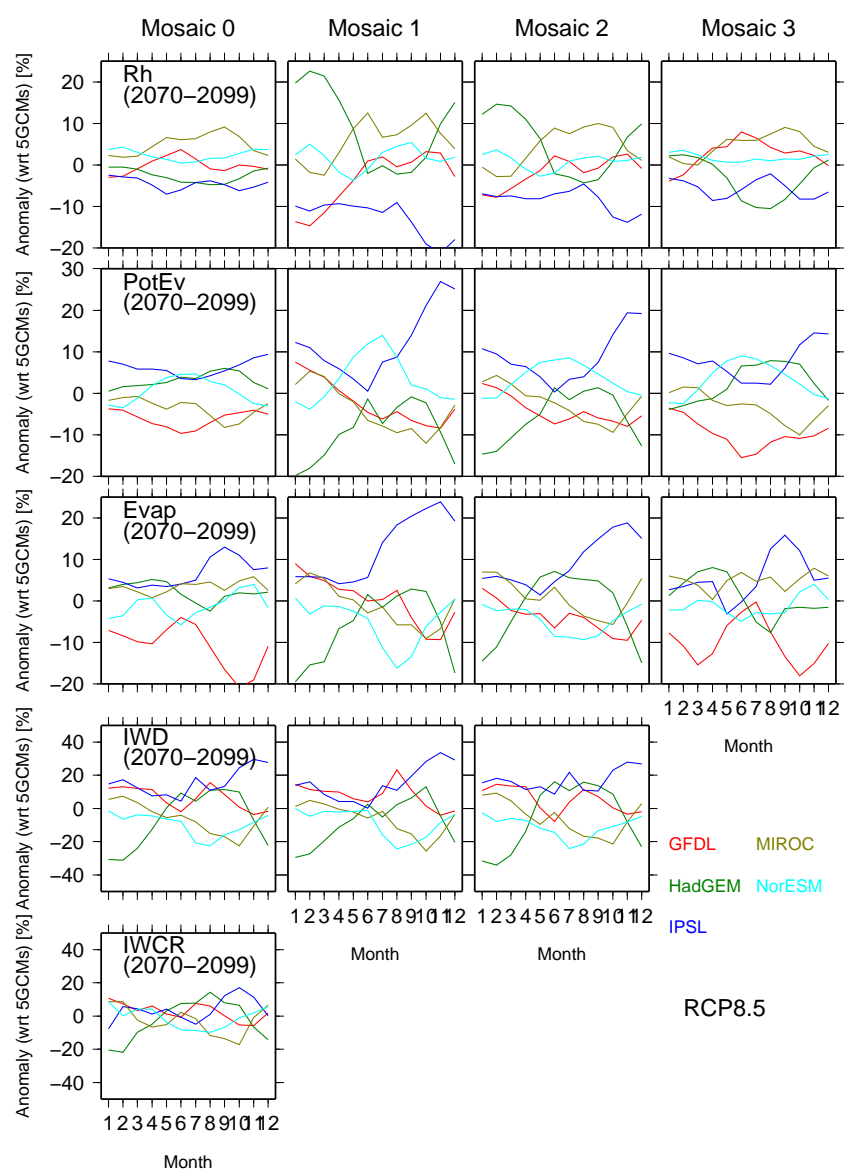

Figure 9. Same as in Fig. 8 but for the future period (2070-2099) under RCP8.5.

biases are comparable to, or sometimes larger than, future changes in IWCR under RCP8.5.

Figure 13 shows the geographical distribution of the sensitivity (i.e., the change in IWD or IWCR per unit change in the relative humidity $(1 \% \mathrm{RH}))$ for June and August. The negative sensitivity of IWD, as expected from Eq. (1), is observed, particularly in India and East China, where both double-cropping and single-cropping irrigated croplands are intensely distributed. In contrast, midlatitudes (Europe to Central Asia and North America) show smaller negative sensitivity than India and East China. This implies that IWD in India and East China is more sensitive to small changes in the relative humidity than other regions of the world, possibly due to the high temperature in summer and the high areal fraction of irrigated cropland.

The sensitivity of IWCR shows a similar geographical distribution to that of IWD but with a smaller magnitude. In June, the negative sensitivity of IWCR is markedly weaker than that of IWD in India and East China. These features are considered to be due to the limited water availability in river flow, which results in less dependence on the atmospheric hu- midity. In fact, the rainy season starts in June in India and in June and July in southern and northern China, respectively.

From these results, to effectively and efficiently reduce the uncertainty of irrigation water consumption, more stringent accuracy for the atmospheric humidity data is required for India and East China.

\subsubsection{Future period (2070-2099)}

Table 5 also shows the results of the sensitivity experiment for the future period. We observed slightly smaller sensitivities ( \pm 6.0 to $\pm 7.5 \%$ for IWD and \pm 3.0 to $\pm 4.5 \%$ for IWCR) for the future period than for the present. Readers are reminded that these sensitivities were evaluated under GCMinherent future climate trends because only the relative humidity was artificially changed around its future projected value while the other variables were fixed to their future projected values in the experiment.

The differences in the relative humidity among the GCMs for the future period (Fig. 7) are sufficiently large for the estimates of IWD and IWCR to diverge. The differences in the relative humidity between the GCMs are one of the marked uncertainty sources in the future projection of hydrological variables.

\subsection{Bias-corrected experiment and effects of reduction of uncertainty across GCMs}

Next, we examine the extent to which uncertainties are reduced by bias correction of the humidity data (Sect. 2.4.2). Figure 14 shows monthly anomalies of hydrological elements with respect to the GCM-ensemble means. In comparison with Fig. 8, the relative humidity of all GCMs is in good agreement, implying that bias correction, even with a primitive method, is effective. The potential evapotranspiration is also similar among the GCMs except for NorESM, which has a positive bias. NorESM also had a positive bias in Fig. 3. The monthly profiles of the evapotranspiration, IWD and IWCR are confined in narrower ranges than those for the uncorrected humidity data. For example, IWD remains within $\pm 20 \%$ from the ensemble mean throughout the year, in clear contrast to the range of approximately $\pm 30 \%$ in Fig. 8. Future projections (Fig. 15, in comparison with Fig. 9) also show the advantageousness of reducing differences in projected hydrological elements across the GCMs by bias correction of the humidity data.

Bias correction of the humidity data also reduces the uncertainties (i.e., the range between the maximum and minimum) in the monthly IWD and IWCR for the five GCMs (Fig. 16). Hereafter, the monthly reduction in uncertainties is quantified as the ratio of the range with bias-corrected humidity data to that with uncorrected humidity data for IWD and IWCR. For 1971-2000, the range of IWD projected with the bias-corrected humidity data is smaller than that with the uncorrected data: the range of the corrected data is $12 \%$ 
Jan. 1971-2000 Jan. 2070-2099(RCP8.5)

GFDL
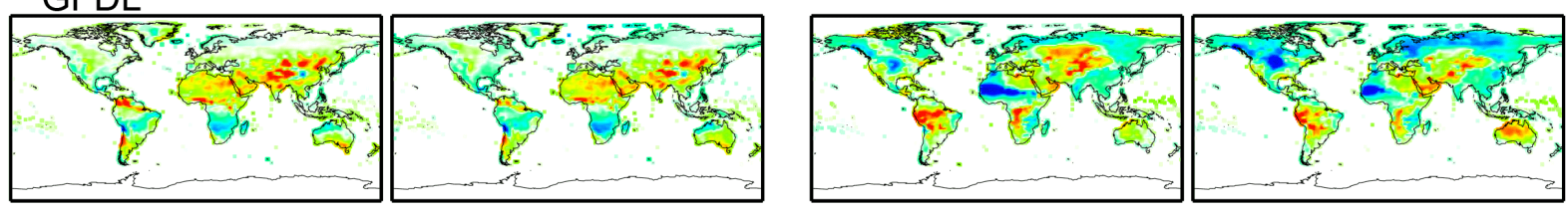

HadGEM
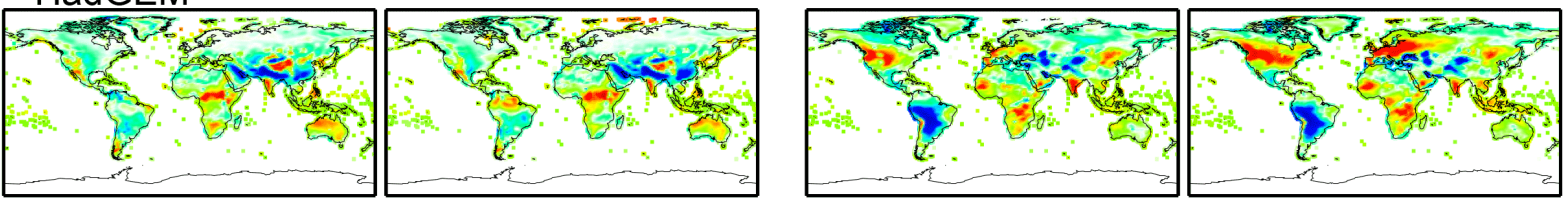

IPSL
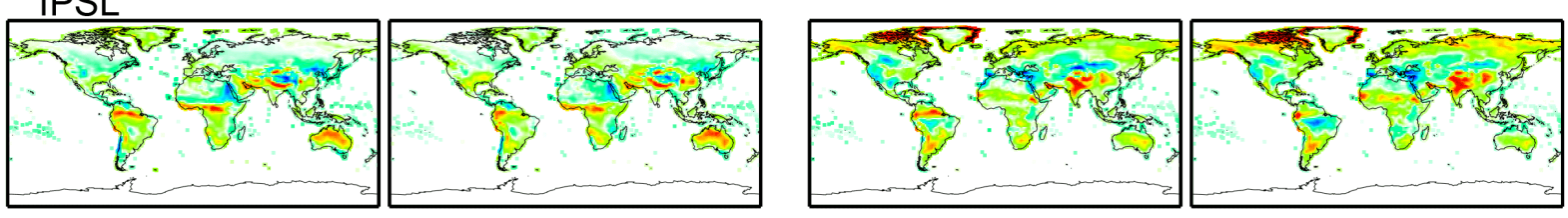

MIROC
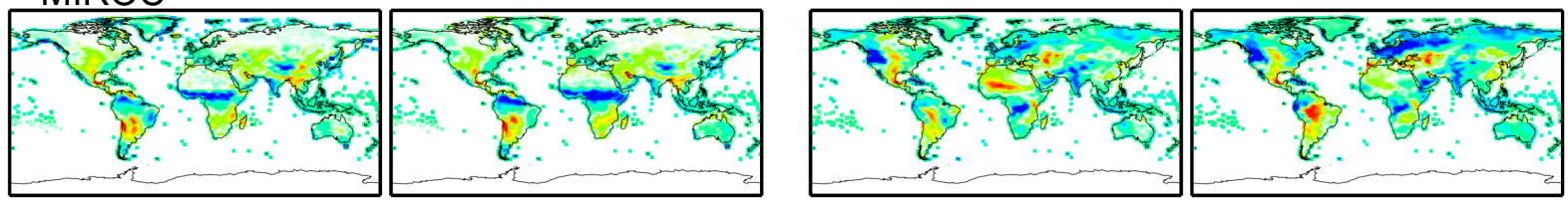

\section{NorESM}
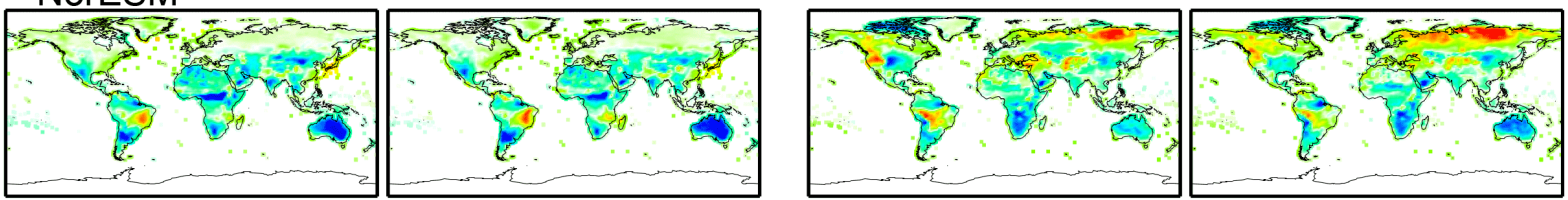

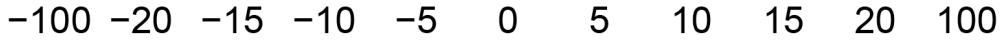 \\ Rh anomaly (wrt 5GCMs) [\%RH]}

Figure 10. Geographical distribution of the monthly anomaly of the relative humidity with respect to the ensemble mean of five GCMs for January (left two columns) and July (right two columns). Each pair of adjoining panels shows results for the present (1971-2000) and future (2070-2099, RCP8.5) periods, respectively.

Table 5a. Results of the reference and sensitivity experiments with artificial biases of $\pm 5 \% \mathrm{RH}-$ irrigation water demand (IWD). The values in parentheses are changes (\%) relative to the original values.

\begin{tabular}{|c|c|c|c|c|c|c|c|c|c|c|}
\hline \multirow{4}{*}{$\begin{array}{l}\text { GCMs } \\
\text { GEDL_ESM2M }\end{array}$} & \multicolumn{10}{|c|}{ Global sum of IWD $\left(\mathrm{km}^{3} \mathrm{yr}^{-1}\right)$ and relative change $(\%)$} \\
\hline & \multirow{3}{*}{$\begin{array}{r}\text { original } \\
(1971-2000) \\
1324.7\end{array}$} & \multirow{2}{*}{\multicolumn{2}{|c|}{$\begin{array}{c}-5 \% \mathrm{RH} \\
(1971-2000)\end{array}$}} & \multicolumn{3}{|c|}{ Mosaic 0} & \multirow{2}{*}{\multicolumn{2}{|c|}{$\begin{array}{c}-5 \% \text { RH } \\
(2070-2099)\end{array}$}} & \multirow{2}{*}{\multicolumn{2}{|c|}{$\begin{array}{c}+5 \% \text { RH } \\
(2070-2099)\end{array}$}} \\
\hline & & & & $\begin{array}{r}+5 \\
(1971\end{array}$ & $\begin{array}{l}6 \mathrm{RH} \\
-2000)\end{array}$ & $\begin{array}{r}\text { RCP8.5 } \\
(2070-2099)\end{array}$ & & & & \\
\hline & & 1414.0 & $(+6.74)$ & 1238.4 & $(-6.51)$ & 1569.7 & 1673.2 & $(+6.59)$ & 1469.7 & $(-6.37)$ \\
\hline HadGEM2-ES & 1295.1 & 1388.8 & $(+7.24)$ & 1204.5 & $(-7.00)$ & 1435.7 & 1536.8 & $(+7.04)$ & 1338.0 & $(-6.80)$ \\
\hline IPSL-CM5A-LR & 1435.5 & 1531.6 & $(+6.69)$ & 1342.3 & $(-6.49)$ & 1703.7 & 1813.9 & $(+6.47)$ & 1596.8 & $(-6.28)$ \\
\hline MIROC-ESM-CHEM & 1161.3 & 1249.9 & $(+7.63)$ & 1075.9 & $(-7.35)$ & 1377.0 & 1477.6 & $(+7.31)$ & 1280.0 & $(-7.04)$ \\
\hline NorESM1-M & 1152.6 & 1236.6 & $(+7.28)$ & 1071.6 & $(-7.03)$ & 1322.6 & 1415.2 & $(+7.00)$ & 1233.1 & $(-6.77)$ \\
\hline
\end{tabular}


Table 5b. Results of the reference and sensitivity experiments with artificial biases of $\pm 5 \% \mathrm{RH}$ - irrigation water consumption from rivers (IWCR). The values in parentheses are changes (\%) relative to the original values.

\begin{tabular}{|c|c|c|c|c|c|c|c|c|c|c|}
\hline \multirow{3}{*}{ GCMs } & \multicolumn{10}{|c|}{ Global sum of IWCR $\left(\mathrm{km}^{3} \mathrm{yr}^{-1}\right)$ and relative change $(\%)$} \\
\hline & \multirow{3}{*}{$\begin{array}{r}\text { original } \\
(1971-2000)\end{array}$} & \multirow{2}{*}{\multicolumn{2}{|c|}{$\begin{array}{c}-5 \% \text { RH } \\
(1971-2000)\end{array}$}} & \multicolumn{3}{|c|}{ Mosaic 0} & \multirow{2}{*}{\multicolumn{2}{|c|}{$\begin{array}{c}-5 \% \text { RH } \\
(2070-2099)\end{array}$}} & \multirow{2}{*}{\multicolumn{2}{|c|}{$\begin{array}{c}+5 \% \text { RH } \\
(2070-2099)\end{array}$}} \\
\hline & & & & $\begin{array}{r}+5 \\
(197\end{array}$ & $\begin{array}{l}\text { \% RH } \\
-2000)\end{array}$ & $\begin{array}{r}\text { RCP8.5 } \\
(2070-2099)\end{array}$ & & & & \\
\hline GFDL-ESM2M & & 543.8 & $(+4.08)$ & 500.9 & $(-4.14)$ & 540.0 & 559.3 & $(+3.57)$ & 520.3 & $(-3.65)$ \\
\hline HadGEM2-ES & 524.9 & 549.4 & $(+4.68)$ & 499.7 & $(-4.79)$ & 532.0 & 554.1 & $(+4.15)$ & 509.6 & $(-4.21)$ \\
\hline IPSL-CM5A-LR & 551.4 & 572.4 & $(+3.81)$ & 529.8 & $(-3.92)$ & 550.5 & 569.1 & $(+3.36)$ & 531.7 & $(-3.42)$ \\
\hline MIROC-ESM-CHEM & 511.6 & 535.7 & $(+4.71)$ & 486.9 & $(-4.84)$ & 506.0 & 525.2 & $(+3.78)$ & 486.5 & $(-3.86)$ \\
\hline NorESM1-M & 497.7 & 521.4 & $(+4.76)$ & 473.7 & $(-4.82)$ & 514.4 & 535.7 & $(+4.13)$ & 492.9 & $(-4.18)$ \\
\hline
\end{tabular}
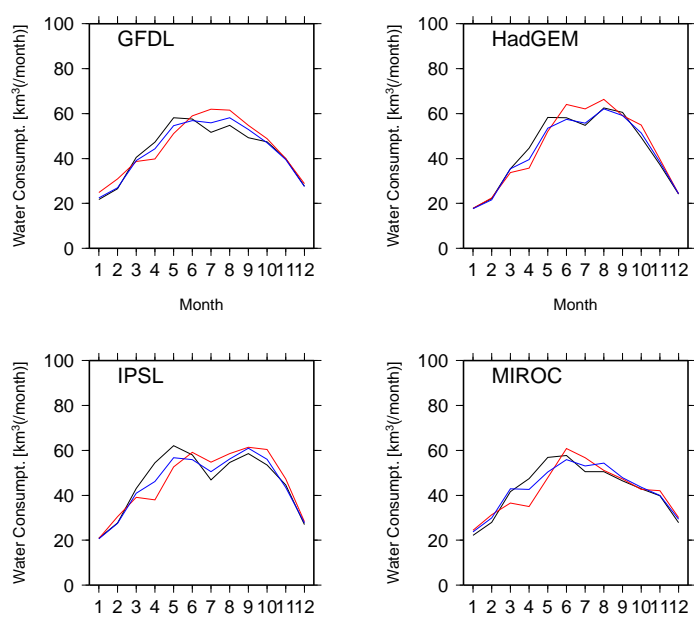

Month

Month

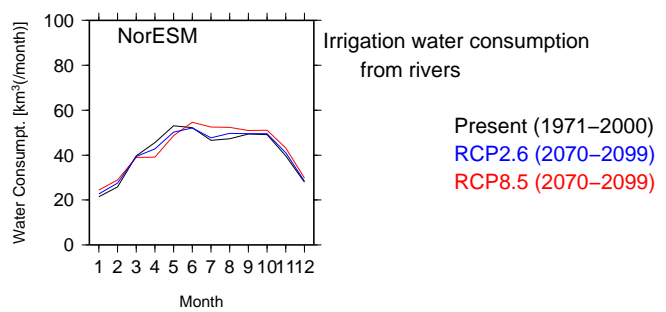

Figure 11. Monthly profiles of the global sum of present and future irrigation water consumption from rivers (IWCR). Black, blue and red lines show the results of the present (1971-2000) estimation and future (2070-2099) projections under RCPs 2.6 and 8.5, respectively.

for the best month (January) and $84 \%$ for the worst month (June). Even for future projections under RCP8.5, the range of IWD with the bias-corrected data is $35 \%$ (best month, January) to $89 \%$ (worst month, August) of that with the uncorrected data. The results for IWCR, which is governed by riverine water availability, also suggest the advantageousness of bias correction of the humidity data: for 1971-2000, the range of IWCR with the bias-corrected data is reduced to as little as $29 \%$ of that with the uncorrected data (February),
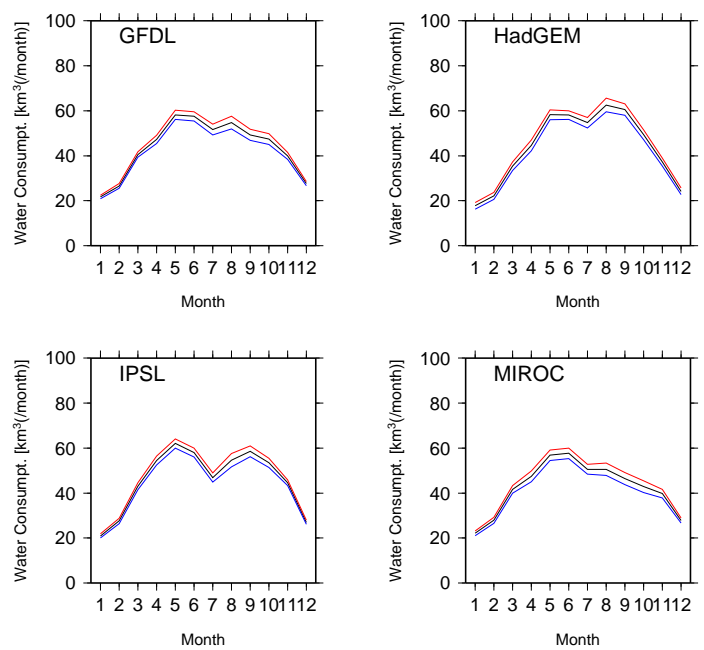

Month

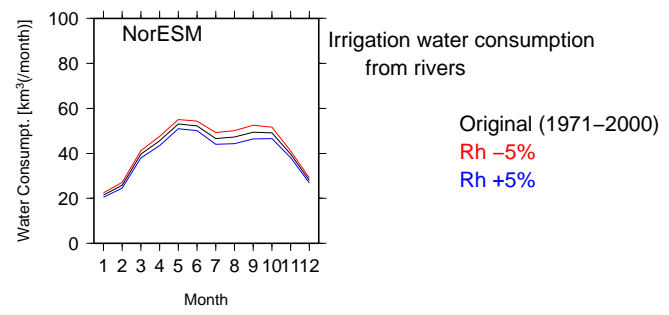

Figure 12. Monthly profiles of the global sum of irrigation water consumption from rivers (IWCR) for the reference and sensitivity experiments with artificial biases of $\pm 5 \% \mathrm{RH}$. The analysis period is 1971-2000.

although the range is increased in June and July (110 and $102 \%$, respectively).

The reduction in uncertainty by bias correction of the humidity was also clearly observed in the absolute annual values of IWD and IWCR. Table 6 shows the annual values of IWD and IWCR and their ranges across the GCMs. The uncertainty ranges with bias-corrected humidity data (bottom line), in comparison with those in Table 4, are reduced from 282.9 to $167.0 \mathrm{~km}^{3} \mathrm{yr}^{-1}$ and from 53.7 to $40.1 \mathrm{~km}^{3} \mathrm{yr}^{-1}$ for the present IWD and IWCR, respectively. Similarly, the range decreases from 381.1 to $214.8 \mathrm{~km}^{3} \mathrm{yr}^{-1}$ and from 44.5 

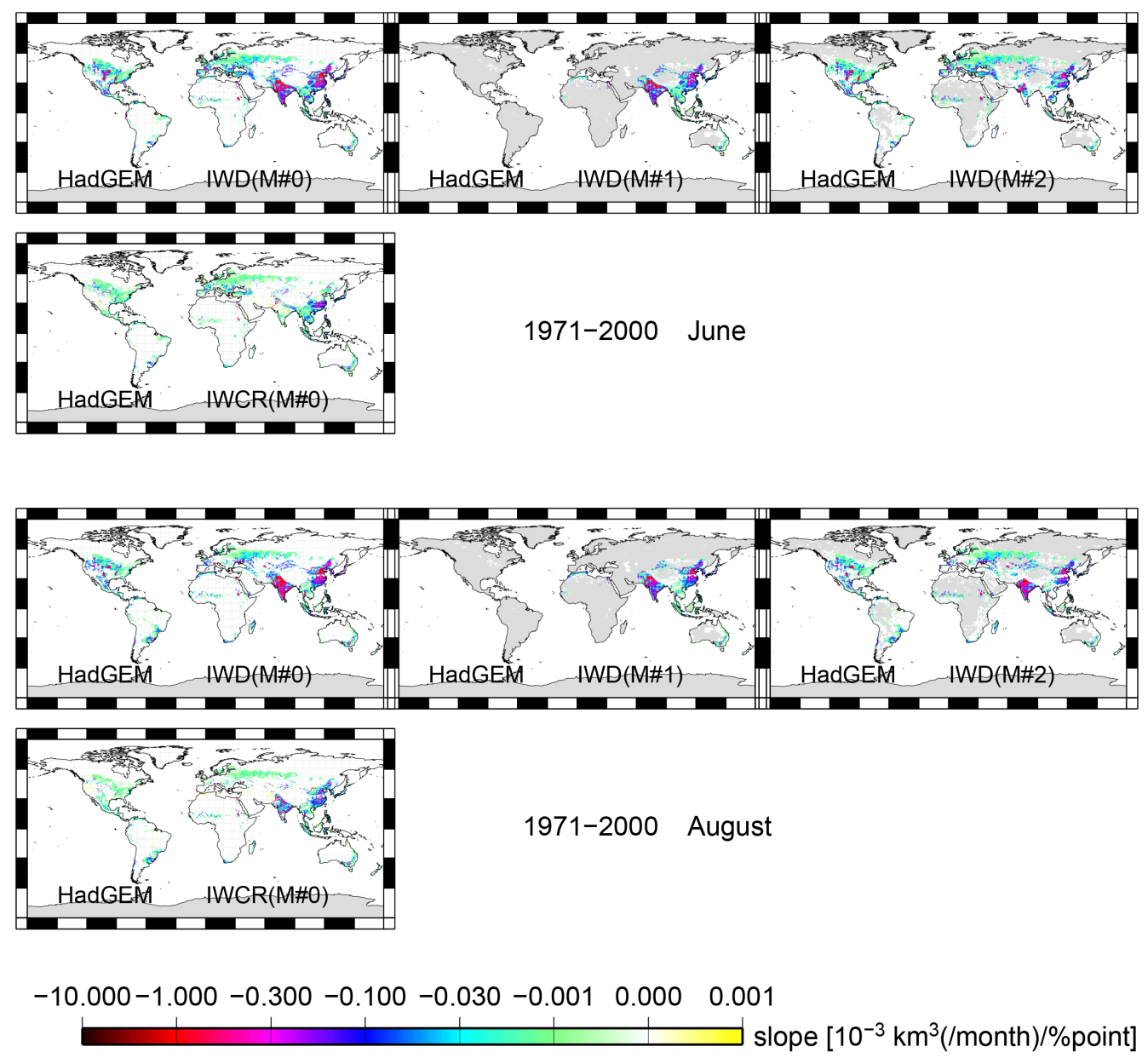

Figure 13. Geographical distribution of sensitivity, given by change in IWD or IWCR per change of $1 \%$ RH in the relative humidity. HadGEM results for June and August are shown.

Table 6. Global sum of irrigation water demand (IWD) and irrigation water consumption from rivers (IWCR) $\left(\mathrm{km}^{3} \mathrm{yr}^{-1}\right)$ with bias-corrected humidity data. See Table 4 for comparison with uncorrected humidity data. The values in parentheses are changes (\%) relative to present values. The range (the difference between the maximum and minimum) of the five GCMs is given in the bottom line.

\begin{tabular}{|c|c|c|c|c|c|c|}
\hline \multirow[t]{2}{*}{ GCMs } & \multicolumn{3}{|c|}{$\operatorname{IWD}\left(\mathrm{km}^{3} \mathrm{yr}^{-1}\right)$} & \multicolumn{3}{|c|}{ IWCR $\left(\mathrm{km}^{3} \mathrm{yr}^{-1}\right)$} \\
\hline & $\begin{array}{r}\text { present } \\
1971-2000\end{array}$ & $\begin{array}{r}\mathrm{R} \\
207\end{array}$ & $\begin{array}{l}P 8.5 \\
-2099\end{array}$ & $\begin{array}{r}\text { present } \\
1971-2000\end{array}$ & $\begin{array}{r}\mathrm{R} \\
207\end{array}$ & $\begin{array}{l}\text { P8.5 } \\
-2099\end{array}$ \\
\hline GFDL-ESM2M & 1282.3 & 1516.4 & $(+18.26)$ & 525.4 & 544.4 & $(+3.62)$ \\
\hline HadGEM2-ES & 1312.4 & 1462.5 & $(+11.44)$ & 542.0 & 542.3 & $(+0.06)$ \\
\hline IPSL-CM5A-LR & 1283.5 & 1526.8 & $(+18.96)$ & 521.1 & 522.8 & $(+0.33)$ \\
\hline MIROC-ESM-CHEM & 1196.0 & 1412.6 & $(+18.12)$ & 522.3 & 515.7 & $(-1.25)$ \\
\hline NorESM1-M & 1145.4 & 1312.0 & $(+14.55)$ & 501.9 & 517.2 & $(+3.06)$ \\
\hline Ensemble mean & 1243.9 & 1446.1 & $(+16.26)$ & 522.5 & 528.5 & $(+1.15)$ \\
\hline Range & 167.0 & 214.8 & & 40.1 & 28.7 & \\
\hline
\end{tabular}

to $28.7 \mathrm{~km}^{3} \mathrm{yr}^{-1}$ for future (RCP8.5, 2070-2099) projections of IWD and IWCR, respectively. Absolute values estimated using a single GCM were also affected by bias correction of the humidity. For example, IPSL shows a large reduction in IWD as a result of bias correction. This indicates that the large IWD values for IPSL in Table 4 can be attributed to biased humidity data. 


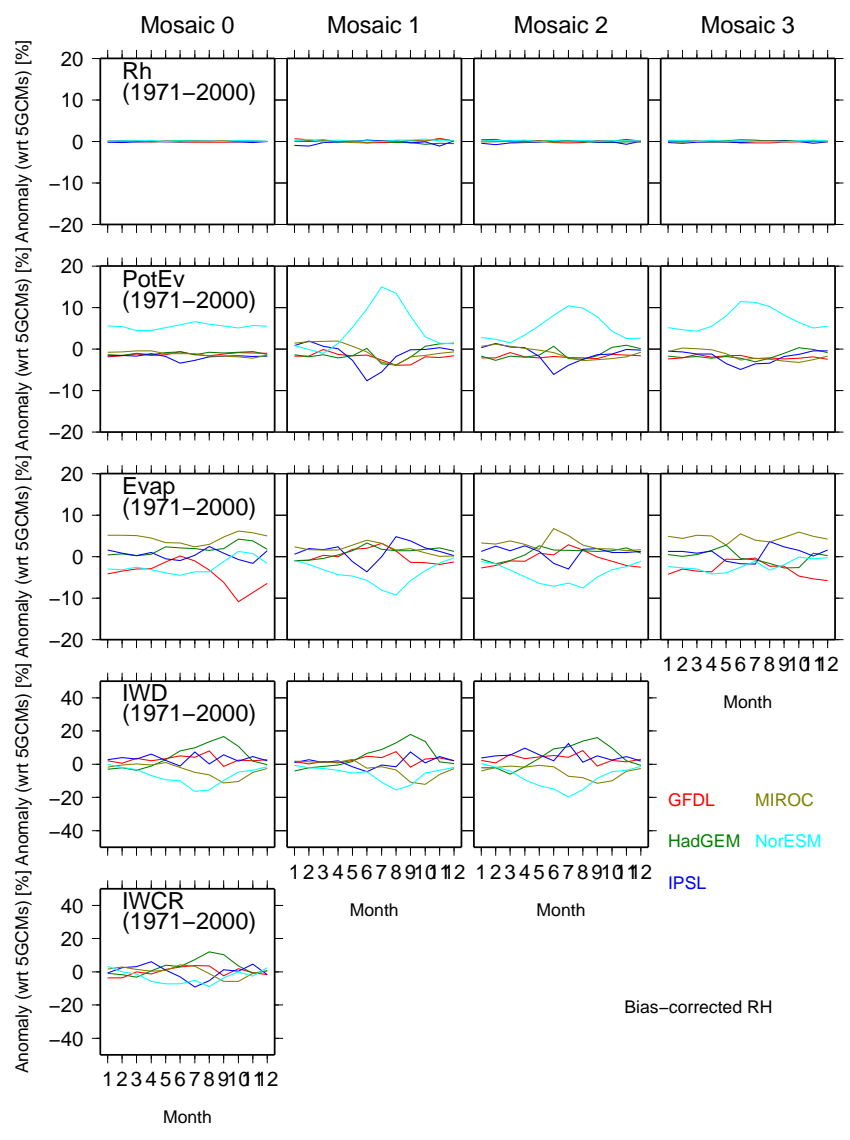

Figure 14. Monthly anomalies with respect to the ensemble mean in five GCMs with bias-corrected humidity data for 1971-2000. The results are aggregated over each land use. The anomaly in each GCM is indicated in different colors: (red) GFDL, (green) HadGEM, (blue) IPSL, (dark yellow) MIROC and (light blue) NorESM. The panels from top to bottom show the relative humidity, potential evapotranspiration, evapotranspiration, irrigation water demand (IWD) and irrigation water consumption from rivers (IWCR).

\section{Discussion}

\subsection{Necessity of bias correction of humidity data}

It is widely known that bias correction is necessary for hydrological simulations with GCM meteorological data because the raw meteorological outputs of GCMs deviate from meteorological observations. The probability density functions of meteorological elements generated by GCMs for a past period often deviate from those of observed elements (e.g., Piani et al., 2010a, b). Since these GCM-inherent features in the humidity affect other hydroclimatological elements and propagate in future projections, we are convinced that bias correction of the humidity, as well as the atmospheric temperature and precipitation, is crucial for analyzing the impact of climate change and also beneficial for dampening GCM-

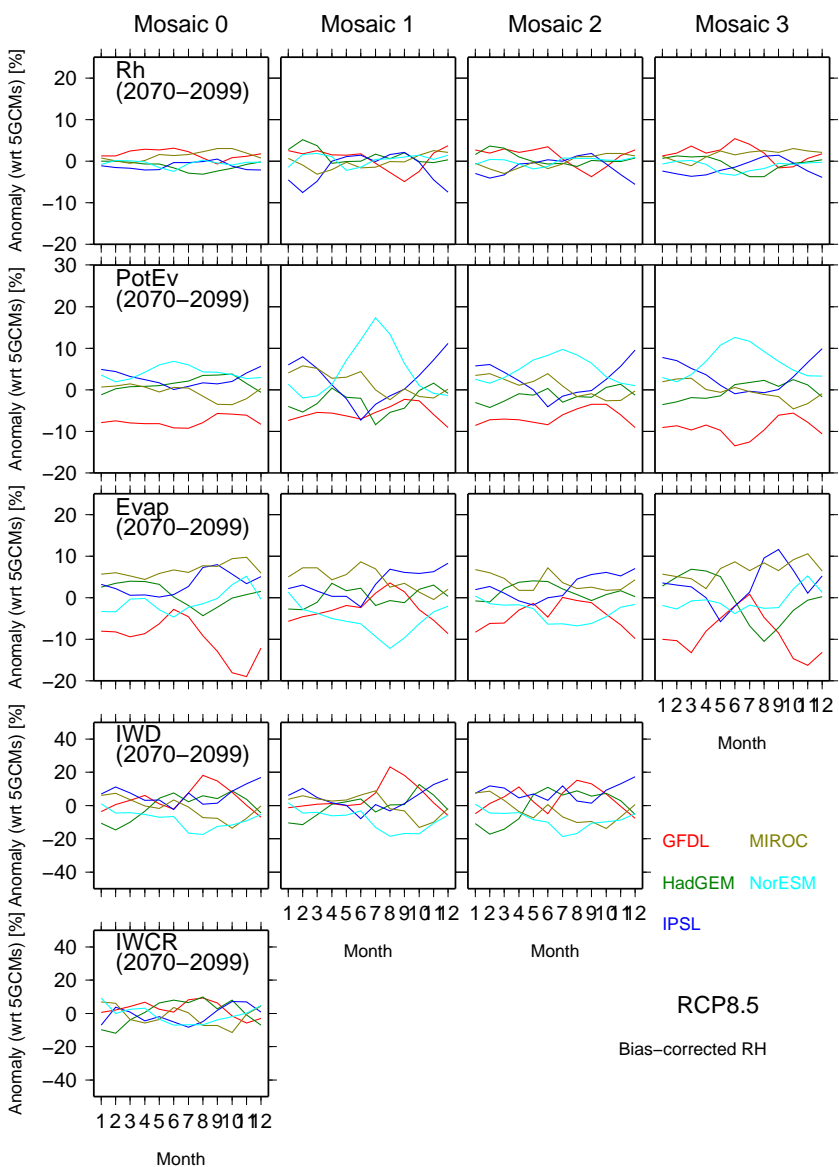

Figure 15. Same as in Fig. 14 but for the future period (2070-2099) under RCP8.5.

inherent features in projections of evapotranspiration and irrigation water consumption.

Owing to the successful removal of GCM biases except for humidity by employing a state-of-the-art methodology (Hempel et al., 2013) (Fig. 2), we can focus on the effects of GCM biases in the humidity in this study. For the present period, since the GCM biases are negligible in other meteorological elements (such as temperature and precipitation), we consider that the differences in evapotranspiration and irrigation water consumption (Figs. 8 and 9) among the GCMs are primarily attributable to GCM biases in the relative humidity. For the future period (Fig. 7), both the humidity biases and the differences in GCM-inherent climate change trends in temperature and/or precipitation can cause differences in evapotranspiration and irrigation water consumption. However, since the monthly anomaly profiles of evapotranspiration and irrigation water consumption tend to show the opposite dependence to that of relative humidity (Fig. 9), and since future monthly anomaly profiles of relative humidity tend to preserve present monthly anomaly profiles (by comparing Fig. 9 with Fig. 8), we consider that biases in relative humidity have a considerable effect on differences in eva- 

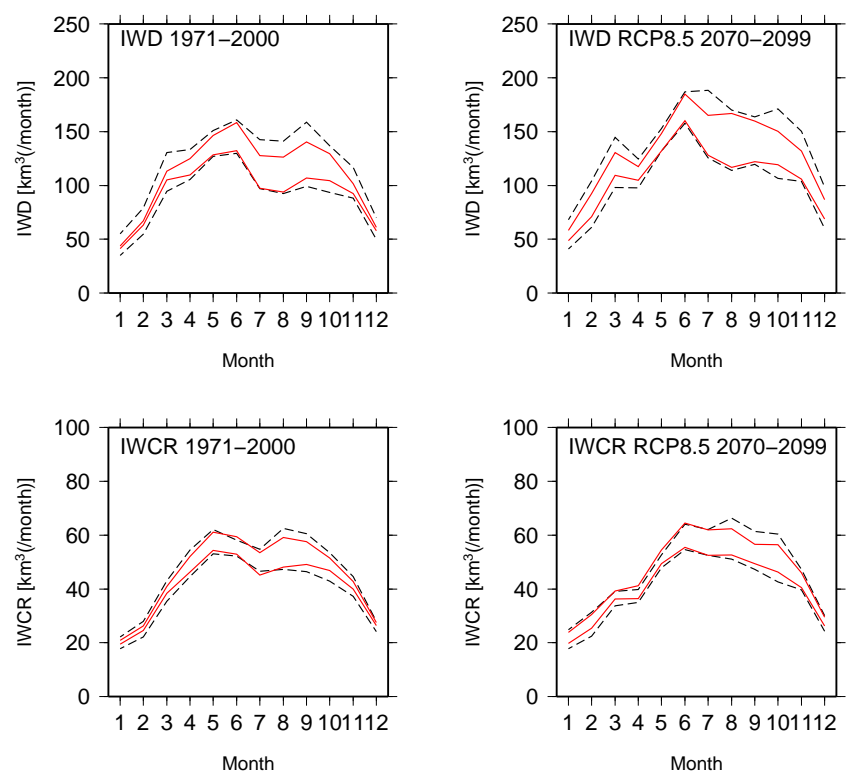

Figure 16. Changes in monthly ranges of irrigation water demand (IWD) and irrigation water consumption from rivers (IWCR) after correcting humidity bias. Broken black and solid red lines show the results with uncorrected and bias-corrected humidity data, respectively. Each pair of lines gives the maximum and minimum values for the five GCMs.

potranspiration and irrigation water consumption across the GCMs. The sensitivity results obtained under future climate conditions (Table 5) by projecting existing humidity differences into the future (Fig. 7) also support this hypothesis.

Although considerable attention has been paid to GCM biases in the temperature and precipitation, less attention has been paid to GCM biases in the humidity. A pioneering study by Haddeland et al. (2012) examined the compound effects of bias corrections of shortwave and longwave radiation, humidity and wind, in contrast to our analysis focusing on the bias correction effects of humidity. They compared hydrological simulations driven by bias-corrected and uncorrected meteorological data and showed that bias correction of radiation, humidity and wind speed increases the agreement with baseline simulations. They also pointed out that bias correction significantly affects the absolute values of simulated runoff and evapotranspiration. In this sense, our results are in agreement with their results. On the other hand, they used four GHMs implementing different potential evapotranspiration formulae (see also Appendix); three of them, LPJmL, WaterGAP (Priestley-Taylor) and MPI-HM (Thornthwaite), are empirical-type formulae that are independent of the atmospheric humidity. Only VIC (Penman-Monteith) is a physical type and dependent on the humidity. Thus, we consider that GHMs with empirical formula are insensitive to uncertainties in humidity data. We will discuss the problem of the GHM dependence on humidity data from a different viewpoint in the next subsection.
Figure 13 implies that the high sensitivity of humidity data over India and East China plays a key role in the uncertainty in the global sum of irrigation water. In these regions, the areal fraction of irrigated cropland is higher than in other regions. Even if the evapotranspiration over a unit area of irrigated cropland was the same over the globe, the total amount of water consumption via evapotranspiration over a unit land area would be larger over densely distributed irrigated cropland than over sparsely distributed irrigated cropland. Moreover, the potential evapotranspiration has higher sensitivity to the atmospheric humidity at higher temperatures than at lower temperatures; since air is able to contain more vapor at higher temperatures, the vapor pressure deficit for a given relative humidity is also larger at higher temperatures.

Moreover, in both India and East China, since future water availability is expected to worsen in these regions owing to an increase in the population and increasing demand for agricultural production, it is highly desirable to accurately estimate future water demand. Some studies (Wada et al., 2010, 2012) have warned that a large volume of irrigation water in excess of recharge is being abstracted from groundwater in India. Water availability is determined by the balance between water supply and demand. Reducing the uncertainties in future projections of irrigation water demand, as well as other factors such as future socioeconomic scenarios and agricultural maneuvers, will help obtain reliable estimates of future water availability. This statement also applies to monthly water availability. In fact, some studies have shown that water availability (or water stress) varies from month to month (Hoekstra et al., 2012; Hanasaki et al., 2013).

\subsection{Caveats on different sensitivities of evapotranspiration to atmospheric humidity}

In climate impact studies on evapotranspiration, since GCM outputs are used as GHM inputs, both GCMs and GHMs may be sources of intermodel differences. Different evapotranspiration formulae adopted in different GHMs may be a source of differences in evapotranspiration among GHMs. The performance of the various evapotranspiration formulae that have been proposed has been primarily examined in comparison with the results of in situ observation (e.g., Winter et al., 1995; Federer et al., 1996; Vörösmarty et al., 1998; Lu et al., 2005; Rao et al., 2011) at various geographical scales. As described in Sect. 2.3 and the Appendix, evapotranspiration formulae are classified into physical and empirical formulae. In practice, since the former formulae require more meteorological elements (e.g., wind, humidity) than the latter, the availability of observed meteorological data is the key to choosing which type of potential evapotranspiration formula to implement.

The existence of these two types of potential evapotranspiration formula indicates that GHMs implementing physical potential evapotranspiration formulae (referred to as phGHMs hereafter) are sensitive to the atmospheric 
humidity, whereas GHMs implementing empirical formulae (emGHMs hereafter) are insensitive to the humidity. Thus, uncertainties in the humidity affect phGHMs but not emGHMs.

Recently, studies on irrigation water published as ISI-MIP Fast Track results have reported future changes in its seasonality (Wada et al., 2013) and the possibility of reduced water availability in river basins due to increasing demand for irrigation water (Haddeland et al., 2014). In both papers, the authors reported that there are large differences in the future projections of hydrological elements among the GHMs. As summarized in Huber et al. (2014), the next impact studies should explore the reasons for intermodel differences to better understand the mechanisms underlying the impact of climate change. However, since each GHM is an assemblage of software modules, every scheme and parameter adopted in each GHM may be a source of intermodel differences. For example, as tabulated in Table S3 of Wada et al. (2013), intermodel differences in the global sum of irrigation water withdrawal among the GHMs are ascribed to differences in not only the evapotranspiration but also the total area of irrigated cropland adopted in the GHMs. We are a long way from identifying possible sources of intermodel differences.

To examine the contributions to uncertainty from smaller components of software, we can take top-down and bottomup approaches. In the former approach, we first evaluate the overall differences, then we allocate them into smaller differences originating from smaller components of software modules. One example of this approach can be seen in Wada et al. (2013), who classified the overall uncertainties into three possible sources (GHMs, GCMs and RCPs) based on the method of Hawkins and Sutton (2009). In the latter approach, as shown in this study, we first obtain differences generated by a single software component and estimate their overall differences. This is laborious but advantageous for identifying contributions from each component or from the calculation process.

We note that a special care should be taken to account for the different sensitivity to the humidity between phGHMs and emGHMs when using a top-down approach. For example, if we deal with both phGHMs and emGHMs together without special care, GCM-inherent humidity biases can be misinterpreted as GHM-inherent features because of the different sensitivity to the humidity.

\subsection{Other factors contributing to uncertainty in future projections of hydroclimatological environments}

Evapotranspiration plays a key role in global water circulation (Oki and Kanae, 2006; Trenberth et al., 2011). Under global warming, the global hydrological cycle is considered to be strengthened owing to intensified precipitation and increasing evapotranspiration. The global energy cycle (Trenberth et al., 2009; Stephens et al., 2012) can be altered by changes in the hydrological cycle via latent heat trans- ported by water vapor flux. It has been a matter of controversy whether the surface humidity will change with climate change. Dai (2006) found that the relative humidity averaged over the global land area remained almost constant during 1976-2004, whereas the specific humidity increased owing to the increasing surface temperature. Willett et al. (2007) showed that the significant increase in surface specific humidity is mainly attributable to human influence by performing a detection-and-attribution analysis. If the climatological relative humidity changes in the future, we should also consider its effects on assessments of the impact of climate change by applying a suitable methodology for bias correction.

We consider that, in a practical sense, bias correction is still necessary for analyzing the impact of climate change to remove GCM-inherent biases. Ehret et al. (2012) posed the controversial but important question of whether we should prioritize the application of bias correction to meteorological inputs because most bias correction methodologies independently correct biases of different elements without considering their mutual physical relations. In fact, as described in Sect. 2.1, humidity-related variables are strictly linked to the atmospheric temperature (and pressure). Moreover, the atmospheric humidity closely interacts with weather conditions (e.g., the humidity is high on rainy days). In this study, sacrificing stringency, we attempted to adjust the monthly climatology of the relative humidity by applying a primitive additive bias correction (Sect. 2.4.2). Even without an advanced methodology, bias correction of the humidity is advantageous in reducing uncertainties in irrigation water across the GCMs. The development of next-generation methodologies of bias correction with physical consistency among meteorological variables would greatly increase the reliability of future projections of hydroclimatological environments.

Although we primarily focused on irrigation water in this study, we did not fully discuss the reduction in evapotranspiration caused by a low soil water content (see Eq. 2) in an explicit manner. Recent studies have addressed the possibility of deficit irrigation, where the irrigation water use is below the optimal level, for irrigated cropland in water-limited areas (Döll et al., 2014). Future changes in global evapotranspiration, including those in areas of rain-fed cropland and natural vegetation, require a more complex discussion because evapotranspiration is determined by not only atmospheric conditions but also soil moisture conditions, which vary with the soil properties and topography. However, the latter has higher geographical diversity than the former because of the dependence on topographical and geological conditions. The in situ observation of soil moisture often shows significant differences at two sites separated by a small distance (Masaki et al., 2011). Jung et al. (2010) showed that the declining trend in global land evapotranspiration since 1998 is attributable to limited soil moisture.

Changes in land use (e.g., transition to irrigated cropland), which are not considered in this study nor in the ISI-MIP 
Fast Track results, also alter the regional water flux between the land and the atmosphere (Gordon et al., 2005). However, such anthropogenic effects are highly dependent on future socioeconomic scenarios, which still contain large uncertainties. If future changes in land use are large, we cannot neglect the feedback process from the land to the atmosphere, and the validity of offline simulation (i.e., GHMs able to run separately with GCMs), which is frequently used in climate impact studies, might become limited.

\section{Conclusions}

We have quantitatively investigated the propagation of uncertainties in humidity data into the estimation of the amount of irrigation water under ongoing climate change. We used bias-corrected meteorological data sets (except for the atmospheric humidity) of five GCMs distributed by the ISI-MIP. We used $\mathrm{H} 08$ for hydrological simulation at the global scale for both present and future periods under four RCPs. H08 employs the bulk formula, which is sensitive to the atmospheric humidity, to calculate the potential evapotranspiration. This study was based on the principle that we should examine one of the possible uncertainty sources in the evaluation of hydrological elements after the removal of bias from the temperature or precipitation by a state-of-the-art bias correction methodology.

The monthly relative humidity of the five GCMs deviated from the observed meteorological data sets (WATCH) by up to ca. $20 \%$ RH for 1970-2000 over global land cells (Mosaic 0). Monthly profiles of the relative humidity showed the characteristics of each GCM, which propagate into monthly profiles of hydrological elements such as evapotranspiration and irrigation water demand obtained by both historical and future simulations. The global sums of irrigation water demand (IWD) and irrigation water consumption from rivers (IWCR), where the latter is constrained by riverine water availability, were evaluated as a reference when we used uncorrected humidity data. The obtained values were widely spread from 1152.6 to $1435.5 \mathrm{~km}^{3} \mathrm{yr}^{-1}$ (range $=282.9 \mathrm{~km}^{3} \mathrm{yr}^{-1}$ ) for IWD and from 497.7 to $551.4 \mathrm{~km}^{3} \mathrm{yr}^{-1}\left(53.7 \mathrm{~km}^{3} \mathrm{yr}^{-1}\right)$ for IWCR between the five GCMs for the present period (1971-2000). Estimations of IWD and IWCR under RCP8.5 (2070-2099) varied from 1322.6 to $1703.7 \mathrm{~km}^{3} \mathrm{yr}^{-1}\left(381.1 \mathrm{~km}^{3} \mathrm{yr}^{-1}\right)$ and from 506.0 to $550.5 \mathrm{~km}^{3} \mathrm{yr}^{-1}\left(44.5 \mathrm{~km}^{3} \mathrm{yr}^{-1}\right)$ between the GCMs, respectively.

A sensitivity experiment involving the uniform addition of hypothetical biases of $\pm 5 \%$ to the humidity data over all land areas showed that the hypothetical biases cause the global sum of IWCR to deviate by \pm 3.5 to $\pm 4.5 \%$. High sensitivity to bias was observed in India and East China, where intensively irrigated cropland is distributed, during the cropgrowing season.
We also found that the bias correction of humidity data can reduce uncertainties in the estimation of IWD and IWCR across the GCMs. Even for a primitive bias correction method that adjusts the monthly climatological humidity of each land cell, we observed a reduction in uncertainties. The ranges across the GCMs for the present and future (RCP8.5) periods were reduced to 167.0 and $214.8 \mathrm{~km}^{3} \mathrm{yr}^{-1}$ for IWD and 40.1 and $28.7 \mathrm{~km}^{3} \mathrm{yr}^{-1}$ for IWCR, respectively. Their ensemble means were less affected by the bias correction. Therefore, the bias correction of the humidity has a merit to narrow the uncertainty range of estimated irrigation water across GCMs. The absolute values obtained using a single GCM were also improved by the bias correction.

We conclude that GCM biases in the humidity propagate into the present and future estimation of hydroclimatological factors such as evapotranspiration and irrigation water. The humidity is one of the important uncertainty sources in evaluating hydrological variables. However, after the successful removal of biases from other meteorological variables, biases in the humidity become a significant uncertainty source. Thus, bias correction of the humidity can reduce uncertainties in the estimation of irrigation water across the GCMs. The results indicate that it is desirable to apply bias correction to not only the atmospheric temperature and precipitation but also the humidity.

Reliable future projections for IWCR are crucial for future projections of water availability, particularly in water-limited regions where different purposes of water abstraction conflict with each other. People living in some river basins have been or will be obliged to make difficult decisions regarding the allocation of water for various purposes in their society because of the increasing demand for water under limited riverine water availability.

Recently, many authors have pointed out the problem of uncertainties in assessing the impact of climate change through research projects such as the ISI-MIP. It is not an easy task to identify possible uncertainty sources from a huge assemblage of models, calculation schemes and parameters. Investigations such as this study will be helpful for identifying sources of uncertainty underlying assessments on the impact of climate change. Although we have a long way to go, reducing the possible uncertainties in studies on the impact of climate change is necessary to obtain a better understanding of future hydroclimatological environments and is an important next step. 


\section{Appendix A: Potential evapotranspiration formulae}

Many formulae for calculating the potential evapotranspiration $E_{\mathrm{pot}}$ have been proposed. The performance of these formulae has been examined in comparison with observed data at various spatial and temporal scales (e.g., Winter et al., 1995; Federer et al., 1996; Vörösmarty et al., 1998; Lu et al., 2005; Rao et al., 2011). Descriptions of these formulae are also given in the abovementioned references and in Shelton (2009); however, here we give some examples of the two types of formulae (physical and empirical; see also Sect. 4.2) that have been implemented in GHMs in studies on the impact of climate change (e.g., Wada et al., 2013; Haddeland et al., 2014; Schewe et al., 2014). The symbols used in the following equations are listed in Table A1.

Table A1. The symbols used in the potential evapotranspiration formulae.

\begin{tabular}{ll}
\hline$\Delta$ & $\begin{array}{l}\text { gradient of saturated vapor pressure } \\
\text { curve vs. air temperature }\end{array}$ \\
$R_{\mathrm{n}}$ & net radiation \\
$G$ & soil heat flux (sometimes $\sim 0)$ \\
$\rho$ & air density \\
$c_{p}$ & specific heat \\
$e$ & vapor pressure \\
$X_{\mathrm{sat}}$ & saturated condition of $X$ \\
$r_{\mathrm{a}}$ & aerodynamic resistance to vapor transfer \\
$\gamma$ & psychrometric constant \\
$r_{S}$ & canopy resistance \\
$C_{\mathrm{D}}$ & bulk transfer coefficient $(0.003)$ \\
$U$ & wind velocity \\
$q$ & specific humidity \\
$T_{\mathrm{S}}$ & surface temperature \\
$c$ & empirical constant \\
$\Lambda$ & daylight hours per day \\
$T_{\mathrm{a}}$ & mean atmospheric temperature \\
$A$ & third-order polynomials of $I$
\end{tabular}

Physical formulae

Penman-Monteith:

$E_{\mathrm{pot}}=\frac{\Delta\left(R_{\mathrm{n}}-G\right)+\rho c_{p}\left(e_{\mathrm{sat}}-e\right) r_{\mathrm{a}}^{-1}}{\Delta+\gamma\left(1+r_{s} r_{\mathrm{a}}^{-1}\right)}$.

Bulk:

$E_{\mathrm{pot}}=\rho C_{D} U\left(q_{\mathrm{sat}}\left(T_{\mathrm{s}}\right)-q\right)$.

Empirical formulae

Priestley-Taylor:

$E_{\text {pot }}=c \frac{\Delta}{\Delta+\gamma}\left(R_{\mathrm{n}}-G\right)$.

Thornthwaite:

$E_{\mathrm{pot}}=1.067 \Lambda\left(\frac{10 \overline{T_{\mathrm{a}}}}{I}\right)^{A}$,

where $I=\sum\left(\frac{\overline{T_{\mathrm{a}}}}{5}\right)^{1.514}$.

Hamon:

$E_{\mathrm{pot}}=\frac{715.5 \Lambda e_{\mathrm{sat}}\left(\overline{T_{\mathrm{a}}}\right)}{\overline{T_{\mathrm{a}}}+273.2}$. 
Acknowledgements. We acknowledge S. Hempel and an anonymous reviewer for their fruitful suggestions for this manuscript. We thank S. Emori, T. Yokohata and H. Shiogama (NIES) for helpful discussions. This research was supported by the Environment Research and Technology Development Fund (S-10) of the Ministry of the Environment, Japan.

This work has been conducted under the framework of the ISIMIP. The ISI-MIP Fast Track project was funded by the German Federal Ministry of Education and Research (BMBF) with project funding reference number 01LS1201A. Responsibility for the content of this publication lies with the authors.

We acknowledge the World Climate Research Programme's Working Group on Coupled Modelling, which is responsible for CMIP, and we thank the climate modeling groups (listed in Sect. 2.1 of this paper) for producing and making available their model outputs. For CMIP, the US Department of Energy's Program for Climate Model Diagnosis and Intercomparison provides coordinating support and leads the development of software infrastructure in partnership with the Global Organization for Earth System Science Portals.

Edited by: C. Franzke

\section{References}

Bruinsma, J.: The resources outlook: by how much do land, water and crop yields need to increase by 2050, in: Looking ahead in world food and agriculture: Perspectives to 2050, edited by: Conforti, P., Food and Agriculture Organization of the United Nations, Rome, Italy, 233-278, 2011.

Center for International Earth Science Information Network (CIESIN) and Centro Internacional de Agricultura Tropical (CIAT), Gridded Population of the World, Version 3, http://sedac. ciesin.columbia.edu/gpw/index.jsp (last access: 5 April 2015), 2005.

Dai, A.: Recent climatology, variability, and trends in global surface humidity, J. Climate, 19, 3589-3606, 2006.

Döll, P. and Siebert, S.: Global modeling of irrigation water requirements, Water Resour. Res., 38, 1037, doi:10.1029/2001WR000355, 2002.

Döll, P., Schmied, H. M., Schuh, C., Portmann, F. T. and Eicker, A.: Global-scale assessment of groundwater depletion and related groundwater abstractions: Combining hydrological modeling with information from well observations and GRACE satellites, Water Resour. Res., 50, 5698-5720, doi:10.1002/2014WR015595, 2014.

Ehret, U., Zehe, E., Wulfmeyer, V., Warrach-Sagi, K., and Liebert, J.: HESS Opinions "Should we apply bias correction to global and regional climate model data?", Hydrol. Earth Syst. Sci., 16, 3391-3404, doi:10.5194/hess-16-3391-2012, 2012.

Elliott J., Deryng, D., Müller, C., Frieler, K., Konzmann, M., Gerten, D., Glotter, M., Flörke, M., Wada, Y., Best, N., Eisner, S., Fekete, B. M., Folberth, C., Foster, I., Gosling, S. N., Haddeland, I., Khabarov, N., Ludwig, F., Masaki, Y., Olin, S., Rosenzweig, C., Ruane, A. C., Satoh, Y., Schmid, E., Stacke, T., Tang, Q. and Wisser, D.: Constraints and potentials of future irrigation water availability on agricultural production under climate change, P. Natl. Acad. Sci. USA, 111, 3239-3244, doi:10.1073/pnas.1222474110, 2014.
Emeis, S.: Measurement Methods in Atmospheric Sciences, In situ and Remote, Gebrüder Borntraeger Science Publishers, Stuttgart, Germany, 257 pp., 2010.

Food and Agriculture Organization (FAO): AQUASTAT website, available at: http://www.fao.org/nr/water/aquastat/main/index. stm (last access: 5 April 2015), 2015.

Federer, C. A., Vörösmarty, C., and Fekete, B.: Intercomparison of models for calculating potential evaporation in regional and global water balance models, Water Resour. Res., 32, 23152321, 1996.

Gordon, L. J., Steffen, W., Jönsson, B. F., Folke, C., Falkenmark, M., and Johannessen, A.: Human modification of global water vapor flows from the land surface, P. Natl. Acad. Sci. USA, 102, 7612-7617, doi:10.1073/pnas.0500208102, 2005.

Haddeland, I., Heinke, J., Voß, F., Eisner, S., Chen, C., Hagemann, S., and Ludwig, F.: Effects of climate model radiation, humidity and wind estimates on hydrological simulations, Hydrol. Earth Syst. Sci., 16, 305-318, doi:10.5194/hess-16-3052012, 2012.

Haddeland, I., Heinke, J., Biemans, H., Eisner, S., Flörke, M., Hanasaki, N., Konzmann, M., Ludwig, F., Masaki, Y., Schewe, J., Stacke, T., Tessler, Z. D., Wada, Y., and Wisser, D.: Global water resources affected by human interventions and climate change, P. Natl. Acad. Sci. USA, 111, 3251-3256, doi:10.1073/pnas.1222475110, 2014.

Hanasaki, N., Kanae, S., Oki, T., Masuda, K., Motoya, K., Shirakawa, N., Shen, Y., and Tanaka, K.: An integrated model for the assessment of global water resources - Part 1: Model description and input meteorological forcing, Hydrol. Earth Syst. Sci., 12, 1007-1025, doi:10.5194/hess-12-1007-2008, 2008a.

Hanasaki, N., Kanae, S., Oki, T., Masuda, K., Motoya, K., Shirakawa, N., Shen, Y., and Tanaka, K.: An integrated model for the assessment of global water resources - Part 2: Applications and assessments, Hydrol. Earth Syst. Sci., 12, 1027-1037, doi:10.5194/hess-12-1027-2008, 2008b.

Hanasaki, N., Inuzuka, T., Kanae, S. and Oki, T.: An estimation of global virtual water flow and sources of water withdrawal for major crops and livestock products using a global hydrological model, J. Hydrol., 384, 232-244, doi:10.1016/j.jhydrol.2009.09.028, 2010.

Hanasaki, N., Fujimori, S., Yamamoto, T., Yoshikawa, S., Masaki, Y., Hijioka, Y., Kainuma, M., Kanamori, Y., Masui, T., Takahashi, K., and Kanae, S.: A global water scarcity assessment under Shared Socio-economic Pathways - Part 2: Water availability and scarcity, Hydrol. Earth Syst. Sci., 17, 2393-2413, doi:10.5194/hess-17-2393-2013, 2013.

Hawkins, E. and Sutton, R.: The potential to narrow uncertainty in regional climate predictions, B. Am. Meteorol. Soc., 90, 10951107, doi:10.1175/2009BAMS2607.1, 2009.

Hempel, S., Frieler, K., Warszawski, L., Schewe, J., and Piontek, F.: A trend-preserving bias correction - the ISI-MIP approach, Earth Syst. Dynam., 4, 219-236, doi:10.5194/esd-4-219-2013, 2013.

Hoekstra, A. Y., Mekonnen, M. M., Chapagain, A. K., Mathews, R. E., and Richter, B. D.: Global monthly water scarcity: blue water footprints versus blue water availability, Plos One, 7, e32688, doi:10.1371/journal.pone.0032688, 2012.

Huber, V., Schellnhuber, H. J., Arnell, N. W., Frieler, K., Friend, A. D., Gerten, D., Haddeland, I., Kabat, P., LotzeCampen, H., Lucht, W., Parry, M., Piontek, F., Rosen- 
zweig, C., Schewe, J., and Warszawski, L.: Climate impact research: beyond patchwork, Earth Syst. Dynam., 5, 399-408, doi:10.5194/esd-5-399-2014, 2014.

ISI-MIP: Fact sheet: bias correction in the ISIMIP, available at: https://www.pik-potsdam.de/ research/climate-impacts-and-vulnerabilities/research/ rd2-cross-cutting-activities/isi-mip/for-modellers/ isi-mip-fast-track/input-data/bias-correction/ bias-correction-fact-sheet (last access: 26 January 2015), 2012.

Jung, M., Reichstein, M., Ciais, P., Seneviratne, S. I., Sheffield, J., Goulden, M. L., Bonan, G., Cescatti, A., Chen, J., de Jeu, R., Dolman, A. J., Eugster, W., Gerten, D., Gianelle, D., Gobron, N., Heinke, J., Kimball, J., Law, B. E., Montagnani, L., Mu, Q., Mueller, B., Oleson, K., Papale, D., Richardson, A. D., Roupsard, O., Running, S., Tomelleri, E., Viovy, N., Weber, U., Williams, C., Wood, E., Zaehle, S., and Zhang, K.: Recent decline in the global land evapotranspiration trend due to limited moisture supply, Nature, 467, 951-954, doi:10.1038/nature09396, 2010.

Kondo, J.: Meteorology of Hydrological Environment, Asakura Shoten, Tokyo, Japan, 368 pp., 1994.

Krysanova, V., Wechsung, F., Arnold, J., Srinivasan, R., and Williams, J.: SWIM (Soil and Water Integrated Model) user manual (version SWIM-8), PIK Report Nr. 69, Potsdam, Germany, 239 pp., 2000.

Leff, B., Ramankutty, N., and Foley, J. A.: Geographic distribution of major crops across the world, Global Biogeochem. Cy., 18, GB1009, doi:10.1029/2003GB002108, 2004.

Lu, J., Sun, G., McNulty, S. G., and Amatya, D. M.: A comparison of six potential evapotranspiration methods for regional use in the southeastern United States, J. Am. Water Resour. As., 41, 621-633, 2005.

Masaki, Y., Ishigooka, Y., Kuwagata, T., Goto, S., Sawano, S., and Hasegawa, T.: Expected changes in future agro-climatological conditions in Northeast Thailand and their differences between general circulation models, Theor. Appl. Climatol., 106, 383401, doi:10.1007/s00704-011-0439-3, 2011.

Monfreda, C., Ramankutty, N., and Foley, J. A.: Farming the planet: 2. Geographic distribution of crop areas, yields, physiological types, and net primary production in the year 2000, Global Biogeochem. Cy., 22, GB1022, doi:10.1029/2007GB002947, 2008.

Moss, R. H., Edmonds, J. A., Hibbard, K. A., Manning, M. R., Rose, S. K., van Vuuren, D. P., Carter, T. R., Emori, S., Kainuma, M., Kram, T., Meehl, G. A., Mitchell, J. F. B., Nakicenovic, N., Riahi, K., Smith, S. J., Stouffer, R. J., Thomson, A. M., Weyant, J. P., and Wilbanks, T. J.: The next generation of scenarios for climate change research and assessment, Nature, 463, 747-756, 2010.

Oki, T. and Kanae, S.: Global hydrological cycles and world water resources, Science, 313, 1068-1072, doi:10.1126/science.1128845, 2006.

Piani, C., Haerter, J. O., and Coppola, E.: Statistical bias correction for daily precipitation in regional climate models over Europe, Theor. Appl. Climatol., 99, 187-192, doi:10.1007/s00704-0090134-9, 2010a.

Piani, C., Weedon, G. P., Best, M., Gomes, S. M., Viterbo, P., Hagemann, S., and Haerter, J. O.: Statistical bias correction of global simulated daily precipitation and temperature for the application of hydrological models, J. Hydrol., 395, 199-215, doi:10.1016/j.jhydrol.2010.10.024, 2010b.

Rao, L. Y., Sun, G., Ford, C. R., and Vose, J. M.: Modeling potential evapotranspiration of two forested watersheds in the Southern Appalachians, Trans. Am. Soc. Agric. Biol. Eng., 54, 2067 2078, 2011.

Rost, S., Gerten, D., Bondeau, A., Lucht, W., Rohwer, J., and Schaphoff, S.: Agricultural green and blue water consumption and its influence on the global water system, Water Resour. Res., 44, W09405, doi:10.1029/2007WR006331, 2008.

Schewe, J., Heinke, J., Gerten, D., Haddeland, I., Arnell, N. W., Clark, D. B., Dankers, R., Eisner, S., Fekete, B. M., ColónGonzález, F. J., Gosling, S. N., Kim, H., Liu, X., Masaki, Y., Portmann, F. T., Satoh, Y., Stacke, T., Tang, Q., Wada, Y., Wisser, D., Albrecht, T., Frieler, K., Piontek, F., Warszawski, L., and Kabat, P.: Multimodel assessment of water scarcity under climate change, P. Natl. Acad. Sci. USA, 111, 3245-3250, doi:10.1073/pnas.1222460110, 2014.

Shelton, M. L.: Hydroclimatology: Perspective and Applications, Cambridge University Press, Cambridge, UK, 426 pp., 2009.

Siebert, S., Döll, P., Hoogeveen, J., Faures, J.-M., Frenken, K., and Feick, S.: Development and validation of the global map of irrigation areas, Hydrol. Earth Syst. Sci., 9, 535-547, doi:10.5194/hess-9-535-2005, 2005.

Stephens, G. L., Li, J., Wild, M., Clayson, C. A., Loeb, N., Kato, S., L'Ecuyer, T., Stackhouse Jr., P. W., Lebsock, M., and Andrews, T.: An update on Earth's energy balance in light of the latest global observations, Nat. Geosci., 5, 691-696, doi:10.1038/NGEO1580, 2012.

Trenberth, K. E., Fasullo, J. T., and Kiehl, J.: Earth's global energy budget, B. Am. Meteorol. Soc., 90, 311-323, doi:10.1175/2008BAMS2634.1, 2009.

Trenberth, K. E., Fasullo, J. T., and Mackaro, J.: Atmospheric moisture transports from ocean to land and global energy flows in reanalyses, J. Climate, 24, 4907-4924, doi:10.1175/2011JCLI4171.1, 2011.

van Vuuren, D. P., Edmonds, J., Kainuma, M., Riahi, K., Thomson, A., Hibbard, K., Hurtt, G. C., Kram, T., Krey, V., Lamarque, J.-F., Masui, T., Meinshausen, M., Nakicenovic, N., Smith, S. J., and Rose, S. K.: The representative concentration pathways: an overview, Climatic Change, 109, 5-31, doi:10.1007/s10584-011-0148-z, 2011.

Vörösmarty, C. J., Federer, C. A., and Schloss, A. L.: Potential evaporation functions compared on US watersheds: possible implications for global-scale water balance and terrestrial ecosystem modeling, J. Hydrol., 207, 147-169, 1998.

Vörösmarty, C. J., Lévêque, C., Revenga, C., Bos, R., Caudill, C., Chilton, J., Douglas, E. M., Meybeck, M., Prager, D., Balvanera, P., Barker, S., Maas, M., Nilsson, C., Oki, T., and Reidy, C. A.: Fresh water, in: Ecosystems and Human Wellbeing: Current State and Trends, The Millennium Ecosystem Assessment Series Volume 1, edited by: Hassan, R., Scholes, R., and Ash, N., Island Press, Washington, D.C., USA, 165-207, 2005.

Wada, Y., van Beek, L. P. H., van Kempen, C. M., Reckman, J. W. T. M., Vasak, S., and Bierkens, M. F. P.: Global depletion of groundwater resources, Geophys. Res. Lett., 37, L20402, doi:10.1029/2010GL044571, 2010. 
Wada, Y., van Beek, L. P. H., and Bierkens, M. F. P.: Nonsustainable groundwater sustaining irrigation: a global assessment, Water Resour. Res., 48, W00L06, doi:10.1029/2011WR010562, 2012.

Wada, Y., Wisser, D., Eisner, S., Flörke, M., Gerten, D., Haddeland, I., Hanasaki, N., Masaki, Y., Portmann, F. T., Stacke, T., Tessler, Z., and Schewe, J.: Multimodel projections and uncertainties of irrigation water demand under climate change, Geophys. Res. Lett., 40, 4626-4632, doi:10.1002/grl.50686, 2013.

Wang, K. and Dickinson, R. E.: A review of global terrestrial evapotranspiration: Observation, modeling, climatology, and climatic variability, Rev. Geophys., 50, RG2005, doi:10.1029/2011RG000373, 2012.

Warszawski, L., Frieler, K., Huber, V., Piontek, F., Serdeczny, O., and Schewe, J.: The inter-sectoral impact model intercomparison project (ISI-MIP): project framework, P. Natl. Acad. Sci. USA, 111, 3228-3232, doi:10.1073/pnas.1312330110, 2014.

Weedon, G. P., Gomes, S., Viterbo, P., Shuttleworth, W. J., Blyth, E., Österle, H., Adam, J. C., Bellouin, N., Boucher, O., and Best, M.: Creation of the WATCH forcing data and its use to assess global and regional reference crop evaporation over land during the twentieth century, J. Hydrometeorol., 12, 823-848, 2011.
Willett, K. M., Gillett, N. P., Jones, P. D., and Thorne, P. W.: Attribution of observed surface humidity changes to human influence, Nature, 449, 710-712, doi:10.1038/nature06207, 2007.

Willett, K. M., Williams Jr., C. N., Dunn, R. J. H., Thorne, P. W., Bell, S., de Podesta, M., Jones, P. D., and Parker, D. E.: HadISDH: an updateable land surface specific humidity product for climate monitoring, Clim. Past, 9, 657-677, doi:10.5194/cp9-657-2013, 2013.

Winter, T. C., Rosenberry, D. O., and Sturrock, A. M.: Evaluation of 11 equations for determining evaporation for a small lake in the north central United States, Water Resour. Res., 31, 983-993, 1995.

Wisser, D., Frolking, S., Douglas, E. M., Fekete, B. M., Vörösmarty, C. J., and Schumann, A. H.: Global irrigation water demand: Variability and uncertainties arising from agricultural and climate data sets, Geophys. Res. Lett., 35, L24408, doi:10.1029/2008GL035296, 2008. 